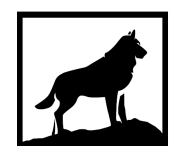

Michigan

Technological

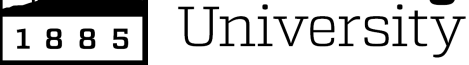

Michigan Technological University

Digital Commons @ Michigan Tech

Dissertations, Master's Theses and Master's Reports

2017

\title{
METHANE FLUXES AND POREWATER DISSOLVED ORGANIC CARBON DYNAMICS FROM DIFFERENT PEATLANDS TYPES IN THE PASTAZA-MARAÑON BASIN OF THE PERUVIAN AMAZON.
}

Jhon del Aguila-Pasquel

Michigan Technological University, jdelagui@mtu.edu

Copyright 2017 Jhon del Aguila-Pasquel

Recommended Citation

del Aguila-Pasquel, Jhon, "METHANE FLUXES AND POREWATER DISSOLVED ORGANIC CARBON DYNAMICS FROM DIFFERENT PEATLANDS TYPES IN THE PASTAZA-MARAÑON BASIN OF THE PERUVIAN AMAZON.", Open Access Master's Thesis, Michigan Technological University, 2017.

https://doi.org/10.37099/mtu.dc.etdr/494

Follow this and additional works at: https://digitalcommons.mtu.edu/etdr

Part of the Other Biochemistry, Biophysics, and Structural Biology Commons, Other Forestry and Forest Sciences Commons, and the Other Plant Sciences Commons 
METHANE FLUXES AND POREWATER DISSOLVED ORGANIC CARBON

DYNAMICS FROM DIFFERENT PEATLANDS TYPES IN THE PASTAZAMARAÑON BASIN OF THE PERUVIAN AMAZON.

\title{
By
}

Jhon del Aguila Pasquel

\begin{abstract}
A THESIS
Submitted in partial fulfillment of the requirements for the degree of MASTER OF SCIENCE

In Forest Ecology and Management
\end{abstract}

MICHIGAN TECHNOLOGICAL UNIVERSITY

2017

C 2017 Jhon del Aguila Pasquel 
This thesis has been approved in partial fulfillment of the requirements for the Degree of MASTER OF SCIENCE in Forest Ecology and Management.

School of Forest Resources and Environmental Science

Thesis Co-Advisor: Rodney A. Chimner

Thesis Co-Advisor: Erik A. Lilleskov

Committee Member: Molly A. Cavaleri

School Dean: Terry Sharik 


\section{Table of Contents}

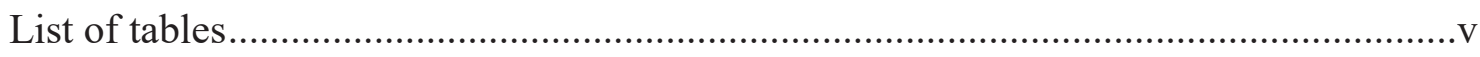

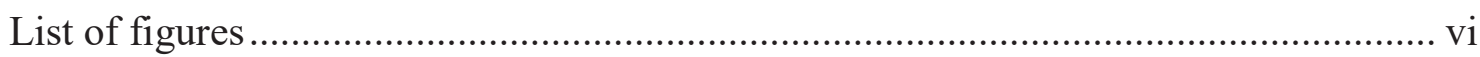

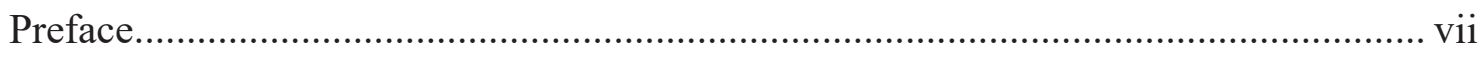

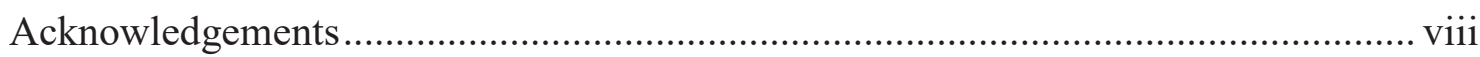

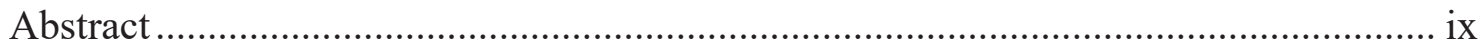

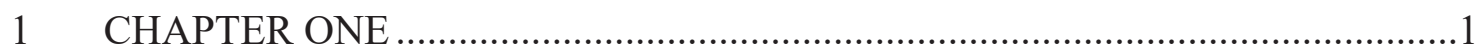

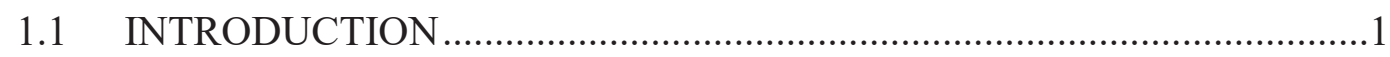

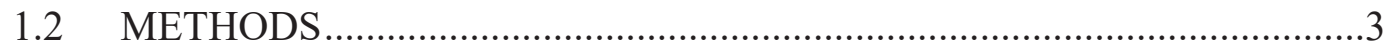

1.2.1 Study area................................................................................

1.2.2 Vegetation and peat characterization ...............................................

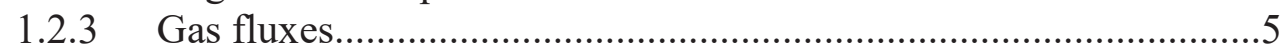

1.2.4 DOC and porewater characterization ..............................................

1.2.5 Ancillary measurements................................................................

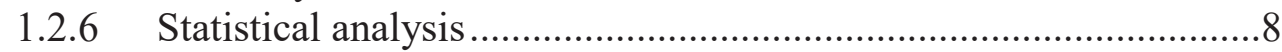

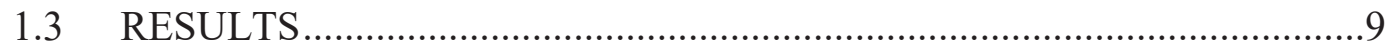

1.3.1 Peat and environmental characterization .......................................9

1.3.2 Vegetation characteristics ..........................................................10

1.3.3 Gas fluxes............................................................................

1.3.3.1 Mixed effect models ......................................................11

1.3.3.2 Relationship with continuous variables ........................11

1.3.4 Porewater DOC characterization and dissolved C gases ................11

1.3.4.1 Mixed effect models .....................................................11

1.3.4.2 Relationship with continuous variables ........................12

1.3.4.3 Other pore water variables ..........................................12

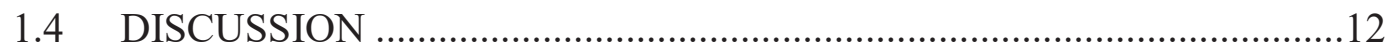

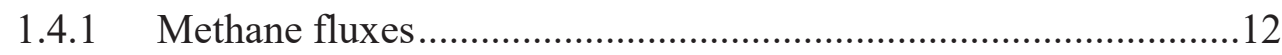

1.4.1.1 Objective: magnitude of $\mathrm{CH}_{4}$ fluxes ............................12

1.4.2 Predictors of methane fluxes............................................................13

1.4.2.1 Objective: predictors of $\mathrm{CH}_{4}$ fluxes ..............................13

1.4.2.1.1 Hypothesis 1 ..........................................13

1.4.2.1.2 Hypothesis 2..........................................14

1.4.2.1.3 Hypothesis 3...........................................14

1.4.2.1.4 Relationship with temperature and sampling date ...............................................................15

1.4.3 Dissolved organic carbon in pore water.........................................16

1.4.3.1 Objective: magnitude of porewater DOC .....................16 
1.4.4 Predictors of dissolved organic carbon in pore water ...................16

1.4.4.1 Objective: predictors of porewater DOC ..................16

1.4.4.1.1 Hypothesis 4......................................16

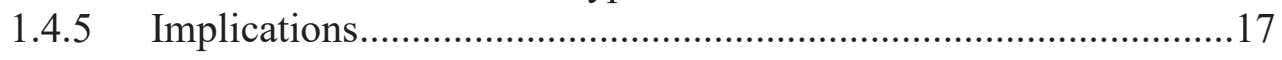

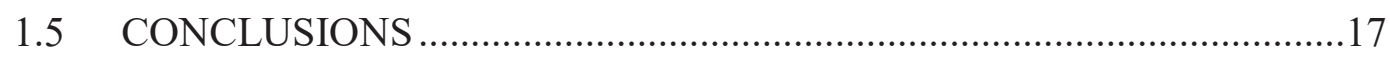

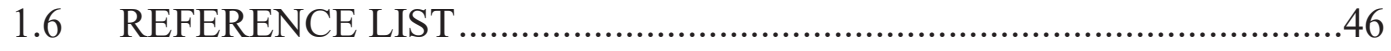




\section{List of tables}

Table 1. Peat depth along the transects in the peatland sites ...................................19

Table 2. Peat properties from cores collected in the palm swamp...........................20

Table 3. Peat properties from cores collected in the open peatland ..........................21

Table 4. Peat properties from cores collected in the pole forest..............................22

Table 5. Relative peak areas (baseline-corrected and normalized to spectral area) derived from peat samples using Fourier-transform infrared analysis.............23

Table 6 . Water chemistry $\left(\mathrm{mg} \mathrm{L}^{-1}\right)$ of porewater from vegetation types ....................24

Table 7. Average values of environmental variables analyzed across vegetation types 25

Table 8. Summary of floristic characterization across vegetation types.....................26

Table 9. Pearson $\left(r, r^{2}\right)$ and Kendall ranked (tau) correlations of environmental variables/porewater chemistry with NMS ordination axes............................27

Table 10. Average soil gas fluxes (all data) by vegetation type ..................................27

Table 11. Ecosystem $\mathrm{CH}_{4}$ fluxes from different plant types in the open peatland .......27

Table 12. Repeated measures mixed effect model analyzing soil $\mathrm{CH}_{4}$ fluxes from the

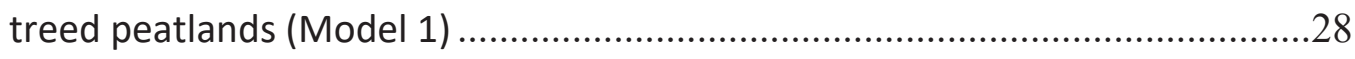

Table 13. Repeated measures mixed effect model analyzing log-transformed ecosystem $\mathrm{CH}_{4}$ fluxes from the open peatland (Model 3) ...............................................28

Table 14. Repeated measures ANCOVA mixed effect model analyzing log-transformed $\mathrm{CH}_{4}$ fluxes from the three vegetation types (Model 2)

Table 15. Average values of porewater variables grouped by vegetation type and depth.

Table 16. Results from a repeated measures mixed effect model analyzing dissolved organic carbon concentration along the vegetation types and among peat depths. 


\section{List of figures}

Figure 1. Rainfall patterns along period 2000-2013 and during the year of sampling...32

Figure 2. Map of PMB indicating the peatland sites (red stars) .................................33

Figure 3. Collar surrounding the culm of sedges in the open peatland (left)................34

Figure 4. Mean non-normalized FTIR spectra of peat sampled at three different depths $(n=2)$

Figure 5 . Water table depth changes by vegetation type along the sampling period ...36

Figure 6. Pneumatophore density variation by vegetation type along the sampling period.

Figure 7. NMS diagram of plots and environmental vectors grouped by vegetation type. 38

Figure 8 . Methane fluxes variation by sampling date

Figure 9. Association between air temperature (all data) and $\mathrm{CH}_{4}$ emissions (soil fluxes from treed peatland + ecosystem fluxes from open peatlands) grouped by vegetation type

Figure 10. Association between pneumatophore density (all data) and soil $\mathrm{CH}_{4}$ emissions grouped by vegetation type.

Figure 11. Variation of DOC concentration by vegetation type across the sampling period.

Figure 12. Association between all peat temperature data and DOC concentrations grouped by vegetation type.

Figure 13. Association between all pneumatophore density data and DOC concentrations grouped by vegetation type 44

Figure 14. Temporal variation of soil methane fluxes grouped by vegetation type and microtopography 


\section{Preface}

The journal article which is included as the main body of this manuscript is planned for submission in the near future and was written by Jhon del Aguila Pasquel.

Data collection was done by del Aguila and Erik Lilleskov. Data processing was done by del Aguila and John Hribljan. Figures and tables were done by Jhon del Aguila.

Rod Chimner provided help with the experimental design, and editing advice and assistance.

John Hribljan provided a great part of the gas and water sampling training, constructed the gas measurement chambers and helped with the experimental design.

Erik Lilleskov helped with the experimental design as well as gave essential editing assistance.

John Stanovick provided crucial help with statistical analysis using mixed models in SAS.

Fred Draper provided part of data for peat characterization as well as helped in the initial selection of sites. 


\section{Acknowledgements}

I would like to thank many people for their help in this thesis. First, I would like to thank my advisors, Rod Chimner and Erik Lilleskov, for his guidance and patience. I would also like to thank John Hribljan for the support and help he has given me during this degree. Thank you to Molly Cavaleri for being part of my committee and her input in this thesis.

Thanks to Instituto de Investigaciones de la Amazonia Peruana (IIAP), SENAMHI, SERNANP, PRONATURALEZA for the support during my research fieldwork in Peru.

Thanks to the SWAMP program for give me the funding to carry out my MS studies.

I would also like to thank to Dennis del Castillo, Euridice Honorio, Fred Draper, Outi Lahtenooja and Kristell Hergoualc'h for his advice during the development of this thesis.

Thanks to John Stanovick for his help in the dark world of statitics.

Thanks to Joseph Shannon, Jennifer Eikenberry, Andrew Burton and Paul Doskey for his help in the lab analysis.

Thanks to Nick Bolton for his help in the initial stage of this thesis.

Thanks to the crew of USFS: Jamie Lamit, Evan Kane, Lynette Potvin, Rose Schwartz and Alex Bales for their support during the last two years.

Thanks to Suzanne Hodgkins and Brittany Verbeke for his help with FTIR analysis

Thanks to José Reyna and Julio Irarica, Nicson and Italo for his help during the fieldwork in Peru.

Thanks to the villagers of 20 de Enero and Nueva York towns for allow me to stay in their towns during the fieldwork in Peru.

Thanks to my friends Ana Maria Planas, Ulises Gracida, Kelsey Carter, Danielle Rupp, James Rauschendorfer and Akwasi Duah-Gyamfi for being kind with this lonely wolf.

Special thanks to the members of my family Maria Elena Rojas, Luciana Victoria del Aguila Rojas and Ana Pasquel for their patience and love during my two years of physical absence. 


\section{Abstract}

Relevant components of the carbon budget such as methane fluxes and porewater dissolved organic carbon (DOC) are poorly characterized in the Peruvian Pastaza Marañon basin (PMB). PMB is associated with a tropospheric hotspot for methane and therefore it may represent a significant methane source. We aimed to quantify the magnitude of $\mathrm{CH}_{4}$ fluxes and porewater DOC; and to determine their predictors across different peatland types in the PMB (open peatland, palm swamp, and pole forest). The study was conducted in two peatland sites covering the three main vegetation types in PMB. We collected gas and water samples using chamber-based techniques and closed piezometers (respectively), covering the entire dry season and the early wet season. We characterized the vegetation, the dissolved and solid peat (spectral indices and FTIR, respectively) and measured ancillary variables such as temperature, water table depth and pneumatophore density. Annual methane fluxes from the PMB were $25.5 \pm 1.9 \mathrm{~g} \mathrm{CH}_{4} \mathrm{~m}^{-2}$ $\mathrm{yr}^{-1}$ and average porewater DOC concentration was $33.1 \pm 0.9 \mathrm{mg} \mathrm{L}^{-1}$. Fluxes were related to plant type (greater in sedges) in open peatlands, pneumatophore density, and air temperature. In contrast, DOC was related to vegetation type (greater in treed peatlands), and peat temperature. Pneumatophore density influenced both methane and DOC dynamics. Our data show much higher methane emissions in peatlands of PMB compared with SE Asian peatlands. Our annual rough estimation (no data from wet season) of $\mathrm{CH}_{4}$ emissions for the entire basin $\left(0.9 \pm 0.1 \mathrm{Tg} \mathrm{CH}_{4} \mathrm{yr}^{-1}\right)$ will help to fill the existing discrepancy between bottom-up and top-down $\mathrm{CH}_{4}$ flux estimations. More research is needed to identify other $\mathrm{CH}_{4}$ sources such as palm-mediated emissions and to evaluate waterborne DOC losses in the PMB. 


\section{CHAPTER ONE}

\subsection{INTRODUCTION}

Peatlands (peat-forming wetlands) are important terrestrial ecosystems due to ecosystem functions such as biodiversity maintenance ${ }^{1}$, regulation of hydrology ${ }^{2}$ and soil-plantatmosphere carbon exchange ${ }^{3}$. Peatlands only cover $\sim 3 \%$ of global land surface area ${ }^{4}$, however they store around $496 \mathrm{Pg} \mathrm{C}\left(1 \mathrm{Pg}=10^{15} \mathrm{~g}\right)^{5,6}$ in their organic soil layer. This is equivalent to $60 \%$ of current concentration of carbon dioxide $\left(\mathrm{CO}_{2}\right)$ in the atmosphere showing their potential as long-term carbon sinks. In addition to sequestering $\mathrm{CO}_{2}$, undisturbed peatlands are also relevant biogenic sources of methane $\left(\mathrm{CH}_{4}\right)^{8}$, which is another important greenhouse gas with a greater global warming potential than $\mathrm{CO}_{2}$.

Tropical peatlands are less studied than northern peatlands ${ }^{9,10}$, and most research on tropical peatlands has been conducted in SE Asia ${ }^{10-13}$. However, recent research efforts have described large tropical peatlands in Africa (Congo) ${ }^{6}$ and South America (Peru) ${ }^{14,15}$. For instance, the Peruvian Pastaza Marañon basin (PMB) has been found to be one of the largest areas of lowland tropical peatland with an area of $\sim 35,600 \mathrm{~km}^{2}$ that sequesters $\sim 3.14 \mathrm{Pg} \mathrm{C}$ in peat ${ }^{6,15}$. PMB contains a mosaic of peatland types occurring along a nutrient status gradient (ombrotrophic-minerotrophic ${ }^{16}$ ) and harbors a unique native vegetation, including native palm trees (Mauritia flexuosa) that create widespread palm swamps over much of the basin $\left(77 \%\right.$ of area $\left.^{15}\right)$. Thus, PMB represents a significant contrast to the mainly forested ombrotrophic systems found in SE Asian peatlands.

Methane emissions measured via ground-based methods are greater in tropical wetlands compared to high-latitude wetlands ${ }^{17}$. These results may validate the large $\mathrm{CH}_{4}$ concentration found in the tropical atmosphere using atmospheric cartography instruments ${ }^{18}$. However, in some regions like northern South America and the Amazon basin there is still a discrepancy between bottom-up (ground) ${ }^{19}$ and top-down (satellite) $\mathrm{CH}_{4}$ estimations ${ }^{17}$. This uncertainty suggests that other sources are still unexplored, which is likely, given that $\mathrm{CH}_{4}$ flux data available from non-Asian tropical peatlands is scarce $^{10,17}$. Likewise, most of hitherto published data from the Amazon basin, which occupies $\sim 33 \%$ of South America ${ }^{20}$, derives from non-peat forming wetlands (floodplains or water bodies) ${ }^{17}$ in the eastern Amazon ${ }^{21,22}$; with few available references from the peatlands of $\mathrm{PMB}^{23-26}$. Therefore, more research is needed to test whether $\mathrm{CH}_{4}$ emissions from PMB may help to fill the gap in the current top-down models ${ }^{27}$.

Variability of $\mathrm{CH}_{4}$ and $\mathrm{CO}_{2}$ soil emissions from peatlands is driven by several abiotic and biotic factors ${ }^{28-30}$. Among abiotic factors, hydrology plays a crucial role controlling peat decomposition by rainfall seasonality ${ }^{31,32}$, changes in water table position, and oxygen availability in peat. Thus, high water tables favor $\mathrm{CH}_{4}$ production while $\mathrm{CO}_{2}$ production is greater at low water tables ${ }^{29,31,33,34}$. In addition, the trophic or nutrient status along with $\mathrm{pH}^{35}$ also influence $\mathrm{CH}_{4}$ fluxes ${ }^{36}$. In northern peatlands, ombrotrophic (only rain-fed, more acidic, often domed, and nutrient-poor) peatlands have on average lower $\mathrm{CH}_{4}$ 
production ${ }^{37}$ compared to minerotrophic (mainly ground water-fed less acidic, and nutrient-rich) ${ }^{38}$ peatlands. Also, microtopography of surface peat (i.e., hummock/lawn) ${ }^{39}$ can be an important predictor of $\mathrm{CH}_{4}$ fluxes from tropical peatlands ${ }^{11,28}$. In hummocks or mounds, the surface oxic layer of the peat profile is thicker, especially when water table drops, promoting $\mathrm{CH}_{4}$ consumption ${ }^{40}$ through aerobic oxidation or methanotrophy ${ }^{41}$, while $\mathrm{CO}_{2}$ fluxes tend to increase ${ }^{42}$. Lastly, other abiotic factors such as peat and air temperature ${ }^{43}$, peat moisture ${ }^{44}$, and peat bulk density ${ }^{36}$ have also been demonstrated to be correlated to $\mathrm{C}$ gas fluxes in peatlands.

Among biotic factors, plant functional traits can have a large influence on methane efflux. Surface vegetation types like Sphagnum, sedges or trees create peat with different qualities by means of their inputs (litterfall and dead roots) ${ }^{45}$ and, consequently, modify $\mathrm{CO}_{2}$ and $\mathrm{CH}_{4}$ production ${ }^{46}$. However, little information exists on how palm-derived peat modifies $\mathrm{CO}_{2}$ and $\mathrm{CH}_{4}$ production. Furthermore, vascular plants release root exudates (labile carbon) into peat profiles ${ }^{47}$, promoting microbial $\mathrm{CH}_{4}$ production (methanogenesis) ${ }^{48}$ through a "priming effect" ${ }^{49}$ or as a direct substrate. Also, autotrophic root respiration represents a significant source of $\mathrm{CO}_{2}$ fluxes in peatlands ${ }^{50}$ that can be reduced by hydrogenotrophic methanogens to produce $\mathrm{CH}_{4}{ }^{41}$. Moreover, wetland plants are aerenchymatous and hence transport oxygen into their root system, creating an oxic layer in the rhizosphere (via radial oxygen loss) ${ }^{51}$ where $\mathrm{CH}_{4}$ may be oxidized to $\mathrm{CO}_{2}$ by methanotrophic bacteria ${ }^{52}$. However, as part of the same process, a complementary "chimney effect" mechanism takes place, allowing $\mathrm{CH}_{4}$ to be effectively transported from peat to atmosphere ${ }^{33,53}$. Other structures such as pneumatophores ${ }^{54}$ and lenticels $\mathrm{s}^{55}$ have been described as suitable conduits for $\mathrm{CH}_{4}$ in tropical ${ }^{55}$ and temperate ${ }^{56}$ forested peatlands ${ }^{57}$, respectively. The native $M$. flexuosa palms that dominate PMB have many pneumatophores as part of their root sytems ${ }^{58}$, but it is unknown if they modify $\mathrm{CH}_{4}$ emissions.

Microbes may use solid phase peat or dissolved organic carbon (DOC) ${ }^{59}$ for production of $\mathrm{CH}_{4}$ and $\mathrm{CO}_{2}$, defining their preference mainly by lability of organic matter and showing different patterns among peatland types ${ }^{60}$. For instance, methanogens in treed tropical peatlands in Borneo have been shown to use both dissolved and solid substrates in similar proportion ${ }^{61}$. DOC is composed by a mixture of labile (e.g. root exudates) and recalcitrant molecules (e.g. humic substances) ${ }^{62}$. The lability of solid phase peat tends to decrease with depth of peat profile ${ }^{63}$. Besides its role as a reactive substrate for microbial decomposition, DOC is a small but important component of carbon budgets in peatlands ${ }^{64}$. DOC of tropical peatlands represents a substantial part of waterborne C exported into rivers and oceans ${ }^{65}$. A variety of factors including hydrology ${ }^{62}$ and surface vegetation ${ }^{64}$ influence the amount of DOC stored in porewater and, potentially, exported as waterborne $\mathrm{C}$ flux ${ }^{10}$. In addition, those factors might also modify the properties of DOC such as reactivity, size, or aromaticity. As in the case of $\mathrm{C}$ gas fluxes, studies based on DOC and its relationship with potential abiotic and biotic predictors, such as water table position and surface vegetation, in non-SE Asian tropical peatlands are scarce ${ }^{66}$. 
A proper assessment of $\mathrm{CH}_{4}$ fluxes and porewater DOC dynamics, as well as their potential predictors, is needed to better understand the role of the PMB in the global carbon budget and how they would react under human-induced disturbance and climate change scenarios. Likewise, our research may be used to generate parameters for peatland ecosystem models and, consequently, improve management practices of non-SE Asian tropical peatlands ${ }^{46}$. Therefore, our objectives are: (1) to quantify the magnitude of $\mathrm{CH}_{4}$ fluxes and porewater DOC; and (2) to determine the predictors of $\mathrm{CH}_{4}$ fluxes and porewater DOC across different peatland types in the PMB.

We hypothesized that (1) greater soil $\mathrm{CH}_{4}$ fluxes are expected in the minerotrophic open peatlands where absence of lignified litter tissue (e.g. branches or stems), along with nutrient availability, will favor a greater peat decomposition. (2) In the open peatland, aerenchymatous species (e.g. sedges) will lead to the greatest ecosystem $\mathrm{CH}_{4}$ fluxes due to their effectiveness to transport $\mathrm{CH}_{4}$ outside of peat profile. (3) Lower $\mathrm{CH}_{4}$ fluxes are expected at lower water table levels and hummock topographic position, while greater pneumatophore density will lead to greater $\mathrm{CH}_{4}$ flux. (4) Greater porewater DOC concentrations are expected under lowered water tables because of enhanced peat decomposition, while vegetation type will also affect DOC concentration because differing litter inputs and root exudates would promote contrasting patterns of solid peat decomposition.

\subsection{METHODS}

\subsubsection{Study area}

The study was conducted in the PMB located in the region of Loreto in northeastern Peru $\left(5^{\circ} \mathrm{S} ; 75^{\circ} \mathrm{W}\right)$. This basin has a mosaic of upland rain forest (terra firme), floodplain, and peatland ecosystems distributed among a network of four main rivers: Pastaza, Marañon, Ucayali, and Amazon ${ }^{15}$. Peatlands have been found to be a mixture of ombrotrophic (rain water fed only) and minerotrophic (surface and groundwater in addition to rain) with roughly equal abundance ${ }^{16}$. Peatlands in PMB exhibit three main types of vegetation: (1) minerotrophic palm swamps locally known as "aguajales" dominated by Mauritia flexuosa palms, (2) ombrotrophic pole forests dominated by woody thin-stemmed and/or low-stature trees locally known as "varillales", and (3) minerotrophic open peatlands dominated by herbaceous species. Climate of the PMB is hot and humid with a very welldefined seasonality of rainfall: the "dry season" occurs during May-October while the "wet season" is from November to April (Figure 1). Weather data recorded by Peruvian Meteorological Service (SENAMHI) is available from a town located along the Marañon River (San Regis; $4.481^{\circ} \mathrm{S} ; 73.974^{\circ} \mathrm{W}$ ): average annual rainfall was $2,910 \mathrm{~mm}$ from 2010 to 2013 . During 2016, average daily temperature and relative humidity was $27.5^{\circ} \mathrm{C}$ and $86.4 \%$, respectively.

We chose two peatlands within the PMB for our investigations (Figure 2). The first peatland, 20 de Enero, is located close to the Yanayacu River $\left(4.670^{\circ} \mathrm{S} ; 73.819^{\circ} \mathrm{W}\right)$ and is 
minerotrophic with areas of undisturbed palm swamps and open peatlands ${ }^{15}$. The second site, Nueva York, is an ombrotrophic peatland close to the Tigre River with pole forest vegetation $\left(4.396^{\circ} \mathrm{S} ; 74.267^{\circ} \mathrm{W}\right)^{16}$. Both the Yanayacu and Tigre are tributaries of the Marañon River.

\subsubsection{Vegetation and peat characterization}

At both sites, sampling was done along a linear transect ( $2700 \mathrm{~m})$. In 20 de Enero site, the transect covered palm swamp and open peatland (Figure 2), whereas the transect in Nueva York was entirely dominated by pole forest. Sampling plots were created every $\sim 300 \mathrm{~m}$ along the transects. We conducted a vegetation survey in each plot dominated by trees or palms (radius: $15 \mathrm{~m}$ and area: $706.86 \mathrm{~m}^{2}$ ). We identified trees/palms at the species level (when possible) and measured diameter of stems greater than $10 \mathrm{~cm}$. In open peatlands, we measured the coverage of herbaceous morphotypes (e.g. sedges, ferns, and floating aquatic plants) along four $15 \mathrm{~m}$-transects placed along the cardinal directions from plot centers.

Longitudinal coverage of microtopography (lawn or hummock) was measured along four $15 \mathrm{~m}$-transects placed inside each plot, except for the open peatlands where hummocks are structurally different (smaller elevation) and covered by ferns or sedges.

Peat depth was measured across the transects in 20 de Enero (every $100 \mathrm{~m} ; 37$ cores) and Nueva York (every $\sim 500 \mathrm{~m} ; 9$ cores) using a Russian peat corer (AMS, American Falls, ID, USA; $5 \mathrm{~cm}$ diameter x $50 \mathrm{~cm}$ height). In 20 de Enero, peat samples from the top 50 $\mathrm{cm}$-section were collected (five $10 \mathrm{~cm}$-layers, 16 cores) and sealed in Whirl-Pak bags in the field. Peat samples from entire cores (i.e. surface to bottom) were also collected (every $\sim 50 \mathrm{~cm}$ ) in 20 de Enero and Nueva York ( 3 and 2 cores, respectively). Upon returning from the field, the peat was frozen for long-term storage. In the lab, peat was dried at $65^{\circ} \mathrm{C}$ until a constant weight was obtained, and weighed to calculate bulk density $\left(\mathrm{g} \mathrm{cm}^{-3}\right)$.

Another set of peat samples (10-20, 30-40, 60-70 cm depth layers) from 7-9 cores of both sites were collected to perform the following analyses: loss-on-ignition (LOI), Fouriertransform infrared (FTIR) spectrometry, carbon (C) and nitrogen (N) content. These samples were also placed and sealed in Whirl-Pak bag in the field and then frozen in the lab. Samples were dried at $65^{\circ} \mathrm{C}$ until a constant weight was obtained and ground with a ball mill (8000 series, SPEX CertiPrep, Metuchen, NJ, USA). For LOI (\%), 0.2-0.5 g of dry peat was ashed in a muffle furnace at $550{ }^{\circ} \mathrm{C}$ for 6 hours. Another peat subsample $(1.8 \mathrm{mg}$ ) was analyzed with an Elemental Combustion System 4100 (Costech Analytical Technologies, Valencia, CA, USA) to obtain C and N content (\%).

FTIR spectra of solid peat were collected with a Spectrum 100 FTIR spectrometer (Perkin Elmer, Waltham, MA, USA) fitted with a CsI beam splitter and a deuterated triglycine sulfate detector. Spectra were acquired in \% transmittance mode between 4000 $650 \mathrm{~cm}^{-1}$ (wavenumber) at a resolution of $4 \mathrm{~cm}^{-1}$, and four scans were averaged for each 
spectrum. A baseline correction was applied to whole spectra with initial sloping baselines using the PerkinElmer 100 Spectrum instrument software. Spectra were then converted to absorbance mode for subsequent data analysis. Peak heights and areas were obtained, baseline-corrected, and normalized to the area of the whole spectrum following a procedure (FTIRbaselines.R) written and tested with R version 3.2.1 (Suzanne Hodgkins and Brittany Verbeke, Florida State University, personal communication, 2017). Peaks used to describe peat quality are based on the following wavenumbers ${ }^{67}$ : (i) 1030 (carbohydrates: cellulose and hemicellulose); (ii) 1510 and 1630 (aromatics: lignin); (iii) 1720 (organic acids: carboxyl or carbonyl); (iv) 2850 (aliphatics: fats, waxes and lipids); and (v) 2920 (aliphatics: fats, waxes and lipids). Peak area calculations are correlated to peak heights $\left(\mathrm{r}^{2}>0.92\right)$, therefore, only the former is displayed in our results.

\subsubsection{Gas fluxes}

Within each forested sample plot, we measured soil respiration and methane fluxes with almost no photosynthetic tissue in collars (few small seedlings present). We placed a polycarbonate collar (40.64 $\mathrm{cm}$ diameter x $10 \mathrm{~cm}$ height) on each microtopographic position. The hummock collar was always placed at the base of an adult palm (where a solid mound of dead organic matter is clearly formed), while the lawn collar (usually small depressions or flat areas where big palms or trees are absent) was placed $\sim 3$ meters away.

In the open peatland, because the herbaceous vegetation was so dense, we measured whole ecosystem respiration and methane flux. Hummock collars were placed surrounding the culm or stalks of sedges or ferns, whereas sponge plants and other lower microforms were within many of the lawn collars. Overall, collars were gently inserted leaving $\sim 5 \mathrm{~cm}$ below peat surface. A boardwalk made of wooden stakes and planks was built to each collar to minimize disturbance during gas sampling.

Measurements of gas fluxes were conducted between 8 am and 4 pm on eight sampling dates over the entire dry season and the beginning of the wet season (June 2016 -January 2017). Gas sampling was performed in an opaque PVC $30 \mathrm{~L}$ chamber (40.64 cm diameter x $25.4 \mathrm{~cm}$ height). A small fan (Double Ball-Bearing, Antec, Fremont, CA, USA)

powered by a $12 \mathrm{~V}$-battery and operating at the lowest speed was incorporated within the chamber to facilitate air mixing. The chamber had a small vent ( $8 \mathrm{~mm}$ inner diameter, 20 cm length tube $)^{68}$ to minimize headspace overpressurization ${ }^{69}$. The chamber was set on the collar and sealed with a $10-\mathrm{cm}$ wide rubber ring. In the open peatland of 20 de Enero, up to two PVC $50 \mathrm{~L}$ extensions (40.64 cm diameter x $38.1 \mathrm{~cm}$ height) were coupled to the chamber to obtain ecosystem gas flux samples by covering the herbaceous plants $(\sim 1$ $\mathrm{m}$ height) present inside the collar (Figure 3 ). The chamber was left to equilibrate on the collar $\sim 5$ min before gas sampling. Then, headspace gas $(\sim 10 \mathrm{ml})$ was extracted from the chambers using a plastic 50 ml-syringe (four times at 15 -minute intervals), stored in a 5.9 $\mathrm{ml}$ evacuated vial (Exetainer, Labco, Lampeter, UK), and shipped to Michigan Tech University. Samples of ambient air were also stored in vials every sampling date. Soil 
$\mathrm{CH}_{4}$ fluxes (in forested sites) include diffusion and ebullition as emission mechanisms, whereas ecosystem fluxes (in the open site, with plants in the chamber) include plantmediated emissions (sedges, ferns and sponge plants from the open peatland) in addition to the previous two mechanisms.

Gas samples were analyzed for $\mathrm{CH}_{4}$ and $\mathrm{CO}_{2}$ using TCD and FID detectors set up in two different gas chromatographs: 6850 Series II (Agilent Technologies, Santa Clara, CA, USA) and CP-3800 (Varian Medical Systems, Palo Alto, CA, USA), respectively. In both analyses, standards were run every 25 samples. To test if shipping altered gas concentrations, a sample of gas standards $(n=16)$ were filled with known $\mathrm{CH}_{4}$ concentrations, sent to Peru and taken into the field, then shipped back to the US and analyzed 3.5 months later. This test showed a negligible $(<1 \%)$ variation in $\mathrm{CH}_{4}$ concentrations. Headspace gas flux $\left(\mathrm{mg} \mathrm{m}^{-2}\right.$ day $\left.^{-1}\right)$ calculation followed these steps: (i) correction of initial headspace concentration due to gas removal during extraction (using ambient air) ${ }^{70}$ and (ii) application of ideal gas law equation (Equation 1) on the slope obtained from the linear regression between corrected headspace concentrations and time of each extraction.

Equation 1:

$$
F_{C H_{4}}=S \frac{\mu m o l}{m o l ~ s e c} \times \frac{P}{1013} \times \frac{273}{273+T_{c}} \times \frac{16.04 k g}{22.414 m^{3}} \times \frac{V m^{3}}{A m^{2}} \times \frac{m o l}{10^{6} \mu m o l} \times \frac{86400 \mathrm{sec}}{d a y} \times \frac{10^{6} \mathrm{mg}}{\mathrm{kg}}
$$

Where:

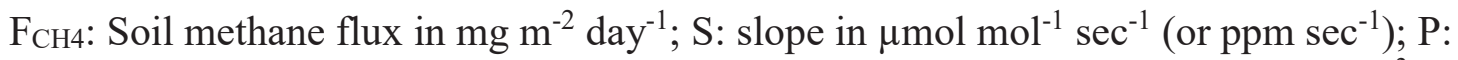
atmospheric pressure in $\mathrm{Pa} ; \mathrm{T}_{\mathrm{c}}$ : Air temperature in ${ }^{\circ} \mathrm{C}$; $\mathrm{V}$ : Volume of chamber in $\mathrm{m}^{3}$; and A: Area of chamber in $\mathrm{m}^{2}$.

A similar equation with gas-specific changes was used to calculate $\mathrm{CO}_{2}$ emissions.

Quality control of $\mathrm{CH}_{4}$ emission data was based on the following procedure: (i) regression lines with well-defined linearity and positive slope were included $\left(r^{2} \geq 0.7\right)$. (ii) When slope was positive and $\mathrm{r}^{2}$ was lower than 0.7 , data was accepted if the coefficient of variation $(\mathrm{CV})$ of the points used for regression was lower or equal than $40 \%$. (iii) Data with negative slopes was included if they had an $\mathrm{r}^{2} \geq 0.7$ as well as a $\mathrm{CV} \leq 40 \%$. Quality control of $\mathrm{CO}_{2}$ fluxes followed a similar procedure with the only difference that data with negative slopes (total excluded: $n=23$ ) was automatically excluded from the final dataset. Overall 30 and 23 values of 382 were excluded from $\mathrm{CH}_{4}$ and $\mathrm{CO}_{2}$ dataset, respectively.

\subsubsection{DOC and porewater characterization}

Porewater from three different layers of peat (10-20, 30-40, and 60-70 cm) was sampled three times (June and August 2016, and January 2017) from a set of piezometers installed 
in 20 de Enero $(\mathrm{n}=8)$ and Nueva York $(\mathrm{n}=7)$. These samples were split in situ for several analyses. First, an aliquot $(15 \mathrm{ml})$ was filtered through $0.45 \mu \mathrm{m}$ nylon membrane filters (GE Healthcare, Chicago, IL, USA), acidified to $\mathrm{pH} 2.0$ with $\mathrm{HCl}$, and stored in dark plastic bottles under refrigeration $\left(4^{\circ} \mathrm{C}\right)$ until DOC and total dissolved nitrogen (TDN) analysis was performed with a Shimadzu TOC-V Combustion Analyzer with a TNM-1 Total Nitrogen module (Shimadzu Scientific Instruments, Columbia, MD, USA) with a detection limit of $0.05 \mathrm{mg} \mathrm{L}^{-1}$ and $0.5 \mu \mathrm{g} \mathrm{L}^{-1}$, respectively.

A second aliquot of filtered water $(\sim 5 \mathrm{ml})$ was used to characterize DOC properties through spectrophotometry analyses. Within $\sim 6$ hours, porewater absorbance was measured with a Blue-Wave Miniature spectrometer (StellarNet, Tampa, FL, USA), attached to a SL5 Deuterium Tungsten Halogen light source (StellarNet, Tampa, FL, USA), using a standard $1 \mathrm{~cm} \mathrm{UV} \mathrm{grade} \mathrm{cuvette} \mathrm{and} \mathrm{DI} \mathrm{water} \mathrm{for} \mathrm{blank.} \mathrm{Ultraviolet-}$ visible spectroscopy or spectral indices were calculated from specific absorption spectra. Specific ultraviolet absorbance (SUVA254) derives from absorption at $\lambda=254 \mathrm{~nm}$ divided by sample DOC concentration. SUVA254 $\left(\mathrm{L} \mathrm{mg} \mathrm{C}^{-1} \mathrm{~m}^{-1}\right)$ is linearly related to size of DOC and a higher ratio indicates a chemical composition dominated by hydrophobic and highly aromatic material ${ }^{71}$. The E2:E3 ratio $(\lambda=254 \mathrm{~nm}$ to $\lambda=365 \mathrm{~nm})$ is also an indicator of DOC size and a smaller ratio means higher aromaticity ${ }^{72}$. The E4:E6 ratio $(\lambda=465 \mathrm{~nm}$ to $\lambda=665 \mathrm{~nm})$ is inversely related to aromaticity and the degree of humification with lower values associated to humic acids ${ }^{73}$.

A third aliquot of porewater (neither filtered nor acidified) was used to strip dissolved $\mathrm{C}$ gases $\left(\mathrm{dCH}_{4}\right.$ and $\left.\mathrm{dCO}_{2}\right)$ from water ${ }^{74}$, following this procedure: (i) Water sample $(40 \mathrm{ml})$ was put into a syringe, then (ii) $40 \mathrm{ml}$ of ambient air was drawn into the syringe creating a 1:1 (v/v) water/air ratio, (iii) the syringe was closed and shaken vigorously for 2 minutes while kept it port-side up, and (iv) $10 \mathrm{ml}$ of headspace gas was injected into an evacuated $5.9 \mathrm{ml}$ Exetainer vial for chromatography analysis as explained in gas fluxes section.

A subset of filtered and acidified porewater aliquots $(15 \mathrm{ml})$ from the $10-20 \mathrm{~cm}$ layer, collected in June 2016, was analyzed for dissolved cations, specifically calcium $\left(\mathrm{Ca}^{+2}\right)$, magnesium $\left(\mathrm{Mg}^{+2}\right)$, iron $\left(\mathrm{Fe}^{+3}\right)$, potassium $\left(\mathrm{K}^{+}\right)$, sodium $\left(\mathrm{Na}^{+}\right)$, nickel $\left(\mathrm{Ni}^{+2}\right)$, and copper $\left(\mathrm{Cu}^{+2}\right)$ using an Optima 7000 DV Inductively Coupled Plasma Optical Emission Spectrometer System (ICP-OES) (PerkinElmer, Waltham, MA, USA).

\subsubsection{Ancillary measurements}

All the following measurements were conducted concurrently to gas sampling on each sampling date. Live pneumatophores were counted inside each collar. Depth to water table was manually measured in an unlined well dug $\sim 20 \mathrm{~cm}$ from each collar that was kept covered with a plastic cap and foam material during the inter-sampling period. The difference of water table between the hole and its contiguous collar was measured using the water bubble leveling technique ${ }^{75}$. Electrical conductivity (not temperature compensated), $\mathrm{pH}$, and temperature of porewater were measured in the well using a 
calibrated meter (YSI 63, Yellow Springs, OH, USA). Peat (at $15 \mathrm{~cm}$ depth) and air temperature were measured next to each collar using a Thermapen digital probe (ThermoWorks, American Fork, UT, USA).

\subsubsection{Statistical analysis}

For our analysis, vegetation types were treated independently of peatland site. Simpson's diversity index was calculated (Past Software, version 3.16$)^{76}$ for vegetation types using the average species area basal (\%) within plots, except in the open peatland where species coverage $(\%)$ within transects and plots were used. Ordination of vegetation, porewater chemistry, and environmental variables (pooled by plot) was conducted with Nonmetric Multidimensional Scaling (NMS) in PC-ORD 5.0 (MJM Software Design) using Sorensen (Bray-Curtis) distance measure and 2-axes as determined by the stress test ${ }^{77}$ (only plots where porewater was collected; $n=15$ ).

The porewater $\mathrm{Ca}^{+2} / \mathrm{Mg}^{+2}$ ratio was used to determine the trophic status of our peatlands. If our ratio was greater compared to that of central Amazonia rainwater (1-3.5) and global average of continental rainwater (2-6), then the peatland must have an additional source of $\mathrm{Ca}^{+2}$ and was considered as minerotrophic ${ }^{75}$. Evaluation of porewater chemistry, $\mathrm{pH}$ and conductivity across vegetation types was conducted with one-way ANOVA using Tukey's post-hoc test (R software, version 3.3.2). For $\mathrm{pH}$ and conductivity, pooled averages per plot were used as "subjects" for the ANOVA test.

We ran a set of mixed effect models (PROC GLIMMIX, SAS 9.4, SAS Institute) to assess the effect of vegetation type, microtopography and date on $\mathrm{CH}_{4}$ fluxes (soil or ecosystem fluxes). Model 1: First, we only used soil $\mathrm{CH}_{4}$ fluxes data from the pole forests and the palm swamps. Model 2: Then, all $\mathrm{CH}_{4}$ flux data from the three vegetation types was used (i.e., including ecosystem fluxes). Model 3: only data from the open peatland was used to analyze the plant type effect (sedge, fern and sponge plant) on the ecosystem $\mathrm{CH}_{4}$ fluxes. We also assessed the influence of environmental variables (pneumatophore density, water table, peat temperature, air temperature) on $\mathrm{CH}_{4}$ fluxes by including them as covariates (ANCOVA). In addition, variation of these environmental variables by vegetation, microtopography, and date were also evaluated using mixed effect models.

Another set of mixed effects analyses was performed to determine the effect of the three vegetation types, depth layer (10-20, 30-40, and 60-70 cm), and date on DOC, TDN, spectral indices (SUVA254, E2:E3, and E4:E6) and dissolved $\mathrm{C}$ gases ( $\mathrm{dCO}_{2}$ and $\left.\mathrm{dCH}_{4}\right)$. In addition, we independently evaluated the effect of pneumatophore density, water table, and peat temperature (average per microtopography) on DOC(ANCOVA).

Overall, the variance matrix of models was blocked by plot (except for model 3), sampling date was the repeated measure and Tukey's tests were used for post-hoc comparison of means. Autoregressive covariance structure was used as determined by looking at the fit statistics and the Kenward and Roger's correction for degrees of 
freedom ${ }^{78}$. Thus, models were iteratively constructed beginning with categorical predictors and their interactions, and followed by the inclusion of single covariates (except for non-ANCOVA models). In models 2 and 3, log-transformation of $\mathrm{CH}_{4}$ fluxes was needed, therefore, a standard amount was added to all fluxes to make them greater than zero and allow their transformation ${ }^{8}$.

Negative values of water table depth indicate water was below the peat surface. Units of methane fluxes are in $\mathrm{mg} \mathrm{m}^{-2} \mathrm{~d}^{-1}$. Throughout the paper, data are presented as means and standard errors $( \pm 1 \mathrm{SE})$, and significance was determined at alpha $=0.05$. Descriptive statistics were generated with Sigmaplot 11.0 (Systat Software) and R version 3.3.2.

Throughout this document we refer to peatlands dominated by trees or palm trees such as the pole forest and the palm swamp as "treed peatlands" for brevity.

\subsection{RESULTS}

\subsubsection{Peat and environmental characterization}

The three vegetation types differed only in terms of peat thickness and carbon concentration, whereas they hadsimilar values for bulk density, percent of organic matter, $\mathrm{N}$ content, and $\mathrm{C} / \mathrm{N}$ ratio. Peat thickness was lower in 20 de Enero $(244.3 \pm 10.4 \mathrm{~cm})$ compared to Nueva York (392.9 \pm 26.4 ; Table 1). Peat bulk density ranged between 0.04 to $0.12 \mathrm{~g} \mathrm{~cm}^{-3}$ (Table 2-4). Percent organic matter was similarly high (>90\%) across the three vegetation types $(\mathrm{p}>0.05)$. Mean $\mathrm{C}$ concentration was greater in the palm swamp $(\mathrm{p}<0.05)$ than the other peatlands (Table $2-4)$. $\mathrm{C} / \mathrm{N}$ ratio values were $22.6 \pm 1.1,22.8 \pm$ 1.5 and $26.1 \pm 1.4$ for pole forest, open peatland, and palm swamp respectively.

The FTIR analysis based on relative peak areas (normalized to spectral area) revealed that pole forest peat had the greatest relative abundances of carbohydrates, organic acids, and aliphatics, followed by the palm swamp peat and the open peatland peat $(p<0.05$; Table 5). The relative abundance of carbohydrates and aromatics (based on peak areas) did not vary with depth in the pole forest, whereas carbohydrates of the open peatland decreased with depth (Table 5). The overall FTIR spectrum of the 10-20 cm layer from the open peatland was elevated compared to the deeper layers, whereas relative absorbance from 30 and $60 \mathrm{~cm}$ depth looked similar across the vegetation types (Figure $3)$.

Porewater data showed the pole forest had the lowest $\mathrm{Ca}^{+2} / \mathrm{Mg}^{+2}$ ratio and $\mathrm{pH}$ confirming its ombrotrophic status. The palm swamp had the highest concentrations of porewater $\mathrm{Ca}^{+2}$ and $\mathrm{Mg}^{+2}$ across the vegetation types $(\mathrm{p}<0.05)$. In addition, concentration of $\mathrm{Fe}^{+3}$, $\mathrm{K}^{+}, \mathrm{Na}^{+}, \mathrm{Ni}^{+}$, and $\mathrm{Cu}^{+}$was similar among the three vegetation types (Table 6). Porewater $\mathrm{pH}$ ranged between 3.5 and 4.6 and electrical conductivity was greatest in the open peatland $(\mathrm{p}<0.01$, Table 7$)$. 
Water table varied by vegetation type, microtopography and sampling date. The lawns of the open peatland had the highest water table $(-1.6 \pm 1.1 \mathrm{~cm})$, whereas water tables were lowest in hummocks of the palm swamp $(-19.7 \pm 2.1 \mathrm{~cm})$ and the pole forest $(-21.2 \pm 1.9$ $\mathrm{cm})$. Likewise, the highest water table occurred in the open peatland during January 2017 (early wet season) while the lowest water table was in the palm swamp at early October 2016 (Figure 4).

Pneumatophore density differed by vegetation type, microtopography and sampling date. No pneumatophores were present in the open peatland while pneumatophore density was similar between the pole forest and palm swamp (Table 7). Among treed peatlands (i.e., pole forest and palm swamp), greatest pneumatophore densities occurred in lawns compared to hummocks $\left(184.0 \pm 24.8\right.$ and $113.6 \pm 17.8$ pneumatophores $\mathrm{m}^{-2}$ respectively). In addition, greatest densities were shown in July 2016 (early dry season), whereas, lowest densities occurred in late-August and January 2017 (mid dry and early wet season; Figure 5).

Temperatures were driven by vegetation type and sampling date. Open peatland had the highest peat, air and porewater temperature compared to the treed peatlands (Table 7).

Hummock coverage was 56 and 58\% in pole forest and palm swamp plots, respectively. In the open peatland, hummocks covered by ferns and sedges represent $\sim 80 \%$ of peat surface (Table 8).

\subsubsection{Vegetation characteristics}

We identified 72 vascular plant species ( 53 trees, 4 palms, 4 shrubs, 8 graminoids 2 forbs and 1 vine) in the plots. Among trees, the most species-rich families were Apocynaceae, Euphorbiaceae, Fabaceae, and Rubiaceae with 5 species each. Mauritia flexuosa palm was the most common species found in the study area, occurring in all palm swamp and pole forest plots (Table 8).

Multivariate Nonmetric Multidimensional Scaling (NMS) separated out three main plant communities and had a 2-dimensional solution with a final stress of 6.82 and a final instability of 0.00 . The three main groupings confirmed our design as they separated out into palm swamp dominated by the M. flexuosa palm and Tabebuia insignis tree, pole forest dominated by thin-stemmed trees Pachira brevipes and Platycarpum sp., and open peatland dominated by sedges (Cyperaceae sp.) and ferns (Blechnaceae sp; Table 8, Figure 6). Most of the variance in the three vegetation groups was explained by axis 1 (49.4\%) that was most related to water table depth (positively, $\mathrm{r}^{2}=0.46$ ) and electrical conductivity (positively, $\mathrm{r}^{2}=0.36$ ); whereas, axis 2 explained $43.1 \%$ of variance and was most related to $\mathrm{Ca}^{+2}$ (positively, $\mathrm{r}^{2}=0.72$ ) and $\mathrm{pH}$ (positively, $\mathrm{r}^{2}=0.56$; Table 9). 


\subsubsection{Gas fluxes}

Soil $\mathrm{CH}_{4}$ fluxes from the treed peatlands were $64.7 \pm 8.8$ and $72.7 \pm 5.4 \mathrm{mg} \mathrm{m}^{-2} \mathrm{~d}^{-1}$ for pole forest and palm swamp respectively (Table 10). The ecosystem $\mathrm{CH}_{4}$ fluxes mediated by sedges $\left(127.6 \mathrm{mg} \mathrm{m}^{-2} \mathrm{~d}^{-1}\right)$ were greater than the other plant types in the open peatland (Table 11). Likewise, soil $\mathrm{CO}_{2}$ flux rates and the ratio of soil $\mathrm{CO}_{2} / \mathrm{CH}_{4}$ were greater in the palm swamp compared to pole forest (Table 10).

\subsubsection{Mixed effect models}

Soil $\mathrm{CH}_{4}$ fluxes from the treed peatlands (pole forest and palm swamp) were only affected by sampling date, whereas other factors did not show any effect (Model 1, Table 12). The same effect occurred when ecosystem $\mathrm{CH}_{4}$ fluxes from the open peatland were included in the analysis (Model 2: soil fluxes from treed peatlands + ecosystem fluxes from open peatlands). Overall, greater emissions occurred at the beginning of August 2016 (early dry season: $\sim 100 \mathrm{mg} \mathrm{CH}_{4} \mathrm{~m}^{-2} \mathrm{~d}^{-1}$ ), whereas lowest were in late November 2016 (early wet season: $\sim 35 \mathrm{mg} \mathrm{CH}_{4} \mathrm{~m}^{-2} \mathrm{~d}^{-1}$, Figure 8). Ecosystem $\mathrm{CH}_{4}$ fluxes from the open peatland were only driven by plant type, with highest emissions associated with sedges, intermediate in sponge plants, and lowest in ferns (Model 3, Tables 11 and 13).

\subsubsection{Relationship with continuous variables}

From all continuous variables included as covariates in our mixed effect models, only pneumatophore density showed a significant relationship with $\mathrm{CH}_{4}$ fluxes (Model 2: soil + ecosystem fluxes). Water table and peat temperature were not linearly associated with $\mathrm{CH}_{4}$ fluxes $(\mathrm{p}<0.05)$. Despite the fact that air temperature was not significant in our ANCOVA mixed effect models, in a linear regression air temperature explained $2 \%$ of $\mathrm{CH}_{4}$ flux ( $<<0.01$, soil + ecosystem fluxes, Figure 9). Pneumatophore density was significant in the ANCOVA mixed effect model $(\mathrm{F}=4.8, \mathrm{p}=0.03$; Table 14) and was directly related to soil $\mathrm{CH}_{4}$ fluxes from the treed peatlands $\left(\mathrm{r}^{2}=0.02, \mathrm{p}<0.01\right.$; Figure 10).

\subsubsection{Porewater DOC characterization and dissolved C gases}

Dissolved organic carbon from porewater was $25.3 \pm 1.2,33.6 \pm 1.6$, and $36.6 \pm 2.0 \mathrm{mg}$ $\mathrm{L}^{-1}$ for the open peatland, the pole forest and palm swamp respectively (Table 15). Some extreme values were excluded from the dataset: seven values ranging from 88 to $550 \mathrm{mg}$ $\mathrm{L}^{-1}$.

\subsubsection{Mixed effect models}

DOC was affected by vegetation type and sampling date, but not by depth of peat profile (Table 16). DOC from the open peatland was $25-30 \%$ lower than DOC from the pole forest and the palm swamp (Table 15). In treed peatlands, highest DOC concentrations occurred during June $2016\left(\sim 37 \mathrm{mg} \mathrm{L}^{-1}\right)$ compared to August and November 2016 (29-33 
$\left.\mathrm{mg} \mathrm{L}^{-1}\right)$, however DOC concentrations from the open peatland were similar among all sampling dates $\left(\sim 25 \mathrm{mg} \mathrm{L}^{-1}\right.$; vegetation $\mathrm{x}$ date: $\mathrm{F}=3.85$ and $\mathrm{p}<0.01$; Figure 11$)$.

\subsubsection{Relationship with continuous variables}

Peat temperature was not significant as a covariate in our DOC models, but in a linear regression peat temperature was inversely related to DOC (Figure 12; $\mathrm{r}^{2}=0.19$ and $\mathrm{p}<0.01)$. Only pneumatophore density was a significant predictor of DOC concentration in our ANCOVA mixed effect models $(\mathrm{F}=6.90, \mathrm{p}=0.01)$ with lower DOC concentrations and absence of pneumatophores coinciding in the open peatland (Figure 13). In a linear regression, pneumatophore density explained a significant fraction of variation in all DOC data $\left(r^{2}=0.37, p<0.01 ;\right.$ Figure 13$)$.

\subsubsection{Other pore water variables}

Most pore water variables varied across the vegetation types except for total dissolved nitrogen and dissolved $\mathrm{CH}_{4}$. Spectral indices (SUVA254, E2:E3, and E4:E6) showed DOC from the open peatland was more decomposed, hydrophobic and aromatic than DOC from the treed-peatlands (all: $\mathrm{p}<0.01$; Table 15). In the open peatland, dissolved $\mathrm{CO}_{2}$ was $\sim 60 \%$ lower compared to pole forest and palm swamp $(\mathrm{F}=13.59, \mathrm{p}<0.01)$. Overall, total dissolved nitrogen, spectral indices and dissolved $\mathrm{C}$ gases changed by sampling date $(\mathrm{p}<0.01)$. Total dissolved nitrogen and SUVA254 values were greater during June 2016 (early dry season), while E2:E3, E4:E6, $\mathrm{dCO}_{2}$ and $\mathrm{dCH}_{4}$ were greater in August 2016 (mid dry season). Only total dissolved nitrogen $(\mathrm{F}=6.75, \mathrm{p}<0.01)$ and $\mathrm{dCH}_{4}$ $(\mathrm{F}=25.42, \mathrm{p}<0.01)$ varied by depth, being elevated at the deeper layer $(65 \mathrm{~cm})$ in both cases, and showing a tendency to increase with depth for $\mathrm{dCH}_{4}$ (Table 15).

\subsection{DISCUSSION}

\subsubsection{Methane fluxes}

\subsubsection{Objective: to quantify the magnitude of $\mathrm{CH}_{4}$ fluxes across different peatland types in the $P M B$}

Methane emissions (soil fluxes in treed peatlands + ecosystem fluxes in open peatlands) coming from the main vegetation types of PMB were $25.5 \pm 1.9 \mathrm{~g} \mathrm{CH}_{4} \mathrm{~m}^{-2} \mathrm{yr}^{-1}$. Our values are greater than soil diffusive $\mathrm{CH}_{4}$ emissions reported for other peatland sites in the PMB $\left(17.6 \pm 1.5 \mathrm{~g} \mathrm{CH}_{4} \mathrm{~m}^{-2} \mathrm{yr}^{-1}\right)^{26}$, peat swamps in Indonesia $\left(<1.36 \pm 0.57 \mathrm{~g} \mathrm{CH}^{2} \mathrm{~m}^{-}\right.$ $\left.{ }^{2} \mathrm{yr}^{-1}\right)^{11}$, and natural northern peatlands $\left(10.1-20.9 \mathrm{~g} \mathrm{CH}_{4} \mathrm{~m}^{-2} \mathrm{yr}^{-1}\right)^{79}$. However, our estimates are similar to those reported for Brazilian wetlands in the Negro River (28 $\mathrm{g}$ $\left.\mathrm{CH}_{4} \mathrm{~m}^{-2} \mathrm{yr}^{-1}\right)^{80}$ and lower than soil emissions from palm swamps and open peatlands of Madre de Dios in South Peruvian Amazon (57.8 $\left.\mathrm{g} \mathrm{CH}_{4} \mathrm{~m}^{-2} \mathrm{yr}^{-1}\right)^{81}$. These comparisons indicate the relevance of tropical peatlands in the global methane budget, the contrast 
between SE Asian and Peruvian peatlands, and the variation of $\mathrm{CH}_{4}$ fluxes between peatlands in the Amazon basin (PMB vs South Amazon).

Based on our $\mathrm{CH}_{4}$ flux data for each peatland type in $\mathrm{PMB}$, coverage by dominant plant (sedge, fern or sponge plant) and microtopography (hummock-lawn) types in the open peatland and the treed peatlands respectively, and estimated area of peatland types ${ }^{15}$ in the PMB, we estimated that $\mathrm{CH}_{4}$ emissions from PMB (soil fluxes in treed peatlands and ecosystem fluxes in open peatlands) was $0.9 \pm 0.1 \mathrm{Tg} \mathrm{CH}_{4} \mathrm{yr}^{-1}$ (rough estimate with no we season data). This estimation along with other available publications for $\mathrm{PMB}^{23-26}$ would help to fill the existing discrepancy between bottom-up and top-down $\mathrm{CH}_{4}$ flux estimations and would support the hypothesis that hotspots of atmospheric methane found in South America by satellite models ${ }^{27}$ and aircraft data ${ }^{82}$ derive from biogenic sources (Amazon floodplain or Bolivian wetlands) ${ }^{82}$.

\subsubsection{Predictors of methane fluxes}

\subsubsection{Objective: to determine the predictors of $\mathrm{CH}_{4}$ fluxes across different peatland types in the PMB.}

1.4.2.1.1 Hypothesis 1: Greater soil $\mathrm{CH}_{4}$ fluxes are expected in the minerotrophic open peatlands where absence of lignified litter tissue (e.g. branches or stems), along with nutrient availability, will favor a greater peat decomposition.

Surprisingly, $\mathrm{CH}_{4}$ fluxes did not change across the vegetation types of PMB despite the clear differences in structure, floristic composition (open peatland vs treed peatlands, Table 8), and trophic status (minerotrophic vs ombrotrophic, Table 6). This finding does not agree with the general pattern shown by peatlands ${ }^{8}$ and other studies in Peruvian Amazon peatlands ( $\mathrm{PMB}^{26}$ and Puerto Maldonado ${ }^{81}$ ) where the vegetation influenced the emissions of methane. Our analysis was only based in two peatland sites and likely including more sites might show different patterns in $\mathrm{CH}_{4}$ emission rates.

Peat quality and DOC quality were different between the open peatland and the treed peatlands, but that difference did not lead to different methane emissions. We found the lowest relative abundance of organic acids and carbohydrates in peat from open peatland (Table 5), indicating more plant decomposition associated to oxidative processes ${ }^{83}$ might be occurring in the treed peatlands compared to the open peatland. Likewise, spectral indices showed that DOC is more aromatic and humified in the open peatland suggesting that most fresh plant material is available in treed peatlands (Table 15). Peat, air and pore water temperature (Table 7) as well as methane in pore water (not significant, Table 15) were greater in the open peatland suggesting an increased microbial activity in terms of methanogenesis. Therefore, we hypothesize that a combination of differing specific below-ground processes is leading to similar final $\mathrm{CH}_{4}$ emissions in both open and treed peatlands: higher temperatures driving consumption of labile organic acids leading to 
more methanogenesis in open peatlands vs availability of fresh material combined with insufficient oxidation by pneumatophores in treed peatlands.

\subsection{Hypothesis 2: In the open peatland, aerenchymatous species (e.g. sedges) will lead to the greatest ecosystem $\mathrm{CH}_{4}$ fluxes due to their effectiveness to transport $\mathrm{CH}_{4}$ outside of peat profile.}

When we moved the analysis from among- to within-vegetation type scale we found that plant type conditioned the ecosystem $\mathrm{CH}_{4}$ fluxes in the open peatland (Table 13, greater emission in sedges). Ecosystem emissions include the three mechanisms of $\mathrm{CH}_{4}$ transport from soil to atmosphere (diffusion, ebullition and plant-mediated). The difference among the three vegetation types might be mainly explained by the presence of aerenchymatous tissue in sedges ${ }^{84}$ and sponge plants ${ }^{85}$ and the lack of aerenchymatous structures showed by several fern species growing in wetlands ${ }^{86,87}$.

Our findings are consistent with previous reports stating that plant-mediated emissions are important sources of $\mathrm{CH}_{4}$ in tropical peatlands ${ }^{88}$ and that the magnitude of theses emissions may change with plant species and size ${ }^{55}$. Methane emissions from stems of $M$. flexuosa palms would increase our estimates of soil fluxes by $\sim 20 \%{ }^{24}$. Considering that palms swamps cover $78 \%$ of the entire basin and $M$. flexuosa is present in both palm swamps and pole forests (54 and $8 \%$ of relative abundance respectively, Table 8 ) we added the $20 \%$ to the palm swamp methane emissions and our final estimate for PMB could reach $1.0 \pm 0.1 \mathrm{Tg} \mathrm{CH}_{4} \mathrm{yr}^{-1}$ (rough estimate without wet season data). It must be considered that this estimate is not including the plant-mediated emissions from woody species (dominant in pole forests, Table 8).

\subsection{Hypothesis 3: Lower $\mathrm{CH}_{4}$ fluxes are expected at lower water table levels and hummock topographic positions, while greater pneumatophore density will lead to greater $\mathrm{CH}_{4}$ fluxes.}

In contract with SE Asian peatlands ${ }^{19}$, methane emissions were not associated with water table positions in any of our models ( $p>0.05)$. It is important to point out that we did not collect data during the mid and late-wet season when water table tend to increase as well as methane emissions. Therefore, this relationship might become significant after a whole-year data collection.

Contrary to our predictions, although water tables rose in the early wet season, average $\mathrm{CH}_{4}$ emission rates were greater during the dry season compared to the early wet season (78.2 vs $44.5 \mathrm{mg} \mathrm{CH}_{4} \mathrm{~m}^{-2} \mathrm{~d}^{-1}$ ). Peat in our sites would be considered as hemic based on Von Post data (scale: 4-5) or fibric based on the lower bulk density $\left(\sim 0.06 \mathrm{~g} \mathrm{~cm}^{-3}\right.$, Tables $2-4)^{89}$, therefore peatlands in PMB have a high water holding capacity which allows them to store vast amounts of water even during the dry season ${ }^{90}$. This volume of water retained in peat creates an anaerobic environment suitable for methanogenesis and, consequently, higher $\mathrm{CH}_{4}$ emission rates even until the middle of the dry season (Figure 8). 
We hypothesize that presence of pneumatophores as part of the root system of $M$. flexuosa palm is highly relevant for $\mathrm{CH}_{4}$ budget in PMB. This root system can reach $\sim 60$ $\mathrm{cm}$ below surface and $40 \mathrm{~m}$ horizontall ${ }^{91}$, explaining the fact that the density of pneumatophores was similar between the pole forest and the palm swamp despite the lower relative abundance of $M$. flexuosa palms in the pole forests. Thus, pneumatophores would cover $\sim 87 \%$ of PMB area $\left(31,418 \mathrm{~km}^{2}\right)^{15}$. Pneumatophores transport oxygen into the peat profile, which would explain the highest abundance of organic acids derived from root exudation and/or oxidation in treed peatlands (Table 5). These organic acids along with carbohydrates are a substrate for methane production that is released to the atmosphere by the pneumatophores. However, pneumatophores also favor the oxidation of methane in shallow peat layers and/or the rhizosphere, explaining the low degree of association found between pneumatophore density and soil $\mathrm{CH}_{4}$ fluxes $\left(\mathrm{r}^{2}=0.02\right.$, Figure 10 ), i.e., the net result of both processes pneumatophore-mediated $\mathrm{CH}_{4}$ emissions and enhanced $\mathrm{CH}_{4}$ oxidation by pneumatophore-fixed $\mathrm{O}_{2}$ would favor methane emissions. Thus, wide-spread palm associated pneumatophores from PMB might partially explain the huge difference in soil $\mathrm{CH}_{4}$ emissions between peatlands of PMB and SE-Asian peatlands ( $\sim 18$ times more emissions in PMB).

In disagreement with our hypothesis, there was no difference between average $\mathrm{CH}_{4}$ emissions of hummocks and lawns (Tables 12 and 14). This pattern parallels the lack of a water table effect. However, emissions from hummocks showed a stronger temporal variation compared to lawns (Figure 14). This finding would also suggest that pneumatophores allow $\mathrm{CH}_{4}$ emissions to keep constant, as more pneumatophores were found in lawns compared to hummocks $\left(276.9 \pm 12.1\right.$ vs $164.5 \pm 9.2$ pneumatophores $\mathrm{m}^{-}$ $\left.{ }^{2}\right)$.

\subsection{Relationship with temperature and sampling date}

Another variable associated with $\mathrm{CH}_{4}$ emissions was air temperature, with greater temperatures recorded in the open peatland (Figure 9). It is well known that methanogenesis is highly sensitive to temperature $\left(\mathrm{Q}_{10}=2\right)^{92}$ and it seems that is a dominant variable in the open peatland where the lack of tree shading leads to higher peat and pore water temperatures. The enhanced methanogenic activity hypothesis might be supported by the lowest amount of carbohydrates and organic acids found in open peatlands (Table 5), indicating an active consumption of these organic compounds by microbes.

Sampling date also was a significant predictor for $\mathrm{CH}_{4}$ emissions (Tables 12 and 14), however we must be cautious about these results because our dataset is strongly timelimited (eight sampling dates in one year) and do not consider diel (within-day), seasonal (complete within-year) and historical (between-years) temporal variation of emissions ${ }^{69}$. In any case, we should point out that soil $\mathrm{CH}_{4}$ fluxes from treed peatlands and both soil fluxes from treed peatlands + ecosystem fluxes from open peatlands showed the same temporal variation in our dataset (Figure 8). 


\subsubsection{Dissolved organic carbon in pore water}

\subsubsection{Objective: to quantify the magnitude of porewater DOC across different peatland types in the PMB}

To our knowledge, our results represent the first published dataset of porewater DOC derived from peatlands in the PMB. The annual average DOC for our study $(33.1 \pm 0.9$ $\mathrm{mg} \mathrm{L}^{-1}$ ) was about the half of porewater DOC concentrations reported for pristine peatlands in SE Asia $\left(62.2 \pm 2.2 \text { and } 68.0 \pm 0.5 \mathrm{mg} \mathrm{L}^{-1}\right)^{64,93}$ and was even lower than deforested peatlands of Borneo $\left(79.9 \pm 5.5 \mathrm{mg} \mathrm{mg} \mathrm{L}^{-1}\right)^{64}$. This marked contrast in DOC concentration as well as in SUVA254 index $(5.7 \pm 0.1$ vs $3.9 \pm 0.3$ for PMB and SE-Asia respectively) might indicate that labile DOC is quickly decomposed by microbial activity and consequently it might be another factor favoring the higher $\mathrm{CH}_{4}$ emissions found in PMB compared to peatlands in SE-Asia ${ }^{11}$.

\subsubsection{Predictors of dissolved organic carbon in pore water}

\subsubsection{Objective: to determine the predictors of porewater DOC across different peatland types in the PMB.}

\subsection{Hypothesis 4: Greater DOC concentrations are expected under lowered water tables because of enhanced peat decomposition, while vegetation type will also affect DOC concentration because differing litter inputs and root exudates would promote contrasting patterns of solid peat decomposition.}

Porewater DOC concentration to $60 \mathrm{~cm}$-depth was not influenced by water table. However, DOC from the open peatland did not vary among our three sampling dates $(\mathrm{p}<0.05$, Figure 11) matching with the lightest change of water table from our three vegetation types (from -10 to $5 \mathrm{~cm}$, Figure 5). In the treed peatlands the highest levels of DOC were found during the early dry season (Figure 11) when water held by fibrichemic peat might avoid the oxidation of DOC, whereas the lowest DOC was found in early August (Figure 11) when oxidation might be more effective due to loss of retained water. Still more sampling dates as well as direct measurements of water holding capacity and porewater turnover are needed to better explain this possible pattern.

The lowest porewater DOC found in the open peatland compare to the treed peatlands (Figure 11) represents an interesting finding that must be analyzed with the other finding related to DOC. Spectral indexes indicate that DOC from the open peatland was more aromatic and well decomposed (Table). The highest peat temperature was found in the open peatland and there was a negative relationship between pore water DOC and peat temperature (Figure 12). There was a lack of pneumatophores in the open peatland and pneumatophore density was directly associated to DOC concentration (Figure 13). Thus, solid peat decomposition and posterior production of labile DOC (more in treed 
peatlands) might be promoted by the oxygen fixed by pneumatophores present in treed peatlands. Although there were aerenchymatous plants in the open peatland, it is unclear how they compare to M. flexuosa in transport of oxygen into the peat. Alternatively, labile DOC released by fine roots of $M$. flexuosa palm, likely associated with pneumatophores, might cause the difference of DOC found between treed and open peatlands. Likewise, higher peat temperatures favored by lack of tree coverage might promote the consumption of DOC by microbial activity and, consequently, the production of methane and carbon dioxide.

\subsubsection{Implications}

Our data show contrasting patterns of methane fluxes and porewater dissolved organic carbon dynamics between peatlands of PMB and SE Asia. These findings indicate that considering a pantropical parameterization of models of these pools and fluxes would not be accurate. Our research is helping to generate parameters for ecosystem models that could be applied for the Pastaza Marañon Basin and to fill the gap existing between atmospheric and ground-based estimations of methane. However, recent studies conducted in other peatlands sites of $\mathrm{PMB}^{26}$ and limitations associated with our research design (number of sites and lack of complete wet season sampling) suggest that more research is needed to better understand the spatial and temporal variation of both methane fluxes and porewater DOC. For example, direct measurements of palm- and treemediated $\mathrm{CH}_{4}$ fluxes would be a nice complement of our research. Likewise, we think our pioneer study about porewater DOC is expected to be the first step for other projects seeking to calculate DOC waterborne losses and, consequently, better understanding the carbon cycle in PMB.

\subsection{CONCLUSIONS}

Methane emissions from the Pastaza Marañon Basin $\left(25.5 \pm 1.9 \mathrm{~g} \mathrm{CH}_{4} \mathrm{~m}^{-2} \mathrm{yr}^{-1}\right)$ are 18fold the soil $\mathrm{CH}_{4}$ fluxes from SE Asian peatlands and annual estimated $\mathrm{CH}_{4}$ emissions for the entire basin is $0.9 \pm 0.1 \mathrm{Tg} \mathrm{CH}_{4} \mathrm{yr}^{-1}$ (rough estimate because we do not have data from wet season). This estimation will help to fill the discrepancy between bottom-up and top-down $\mathrm{CH}_{4}$ flux estimations. Based in our findings, methane fluxes are conditioned by micro-scale variables such as plant type in the open peatlands, air temperature and pneumatophore density.

Annual estimated porewater DOC in the Pastaza Marañon Basin is much lower than estimates for pristine, deforested and drained peatlands of SE Asia. Variation of DOC concentration is associated to vegetation type, decomposition status of peat (fibrichemic), quality of DOC, peat temperature and pneumatophore density. We hypothesize that the highest emissions of $\mathrm{CH}_{4}$ were associated with lower DOC concentrations because labile DOC can be used as a substrate by microbes responsible of methanogenesis. Likewise, it seems that pneumatophores belonging to the root system of M. flexuosa palm are highly relevant for the carbon cycle in the peatlands of PMB 
because they are strongly involved in the dynamics of methane and dissolved organic carbon. 


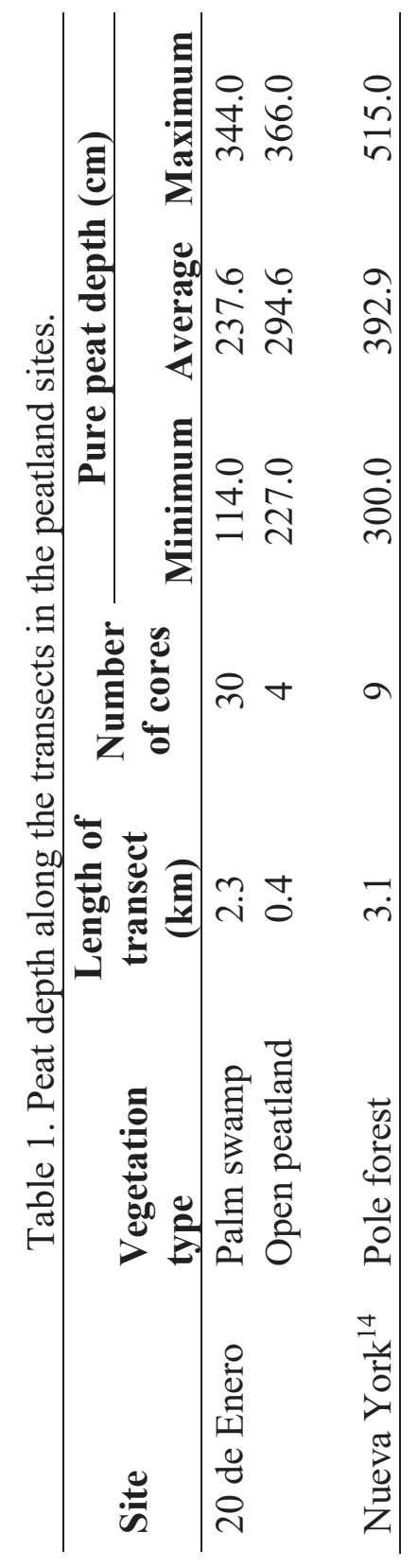

$\frac{\frac{0}{0}}{\frac{\pi}{0}}$ 


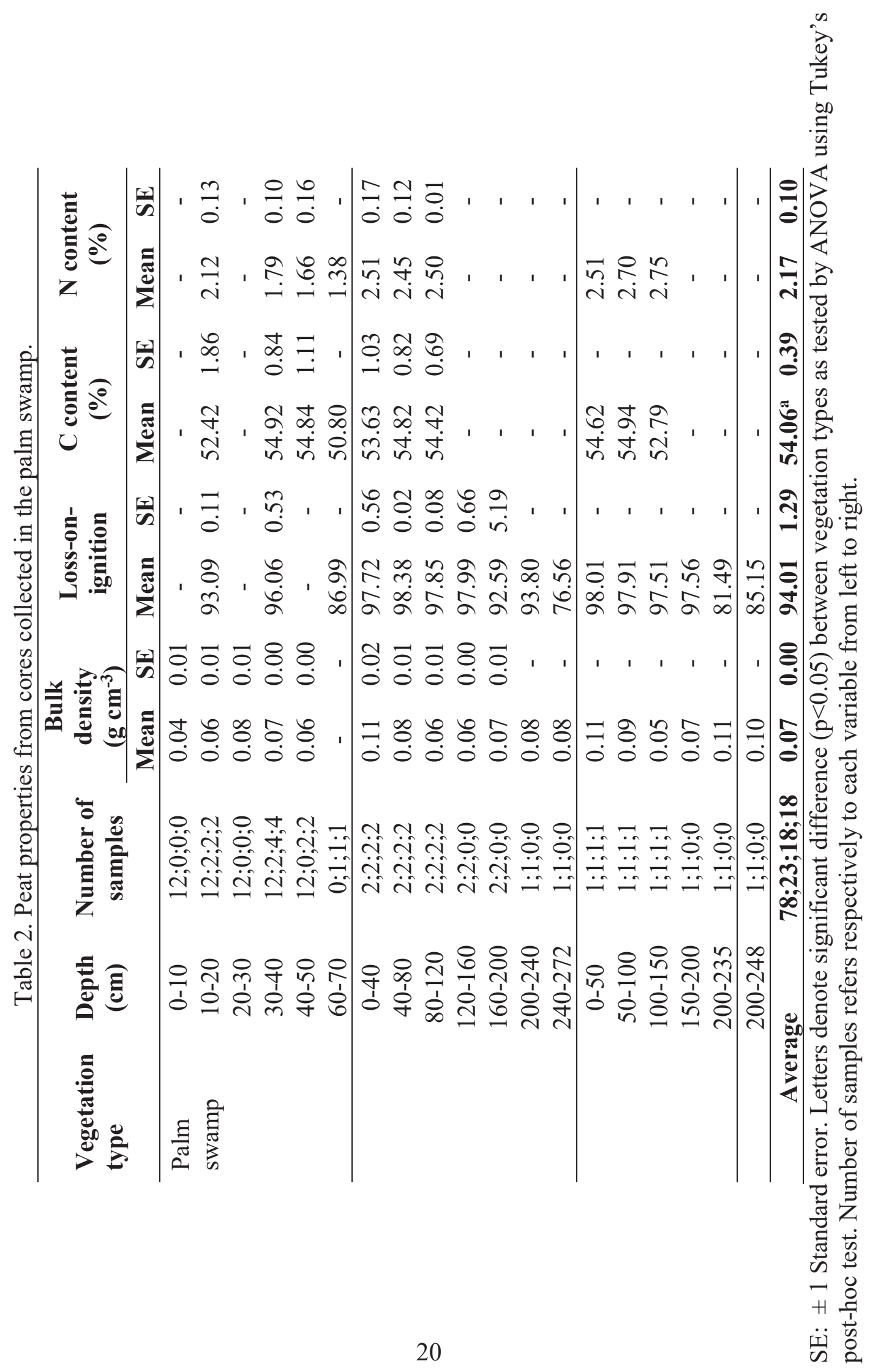




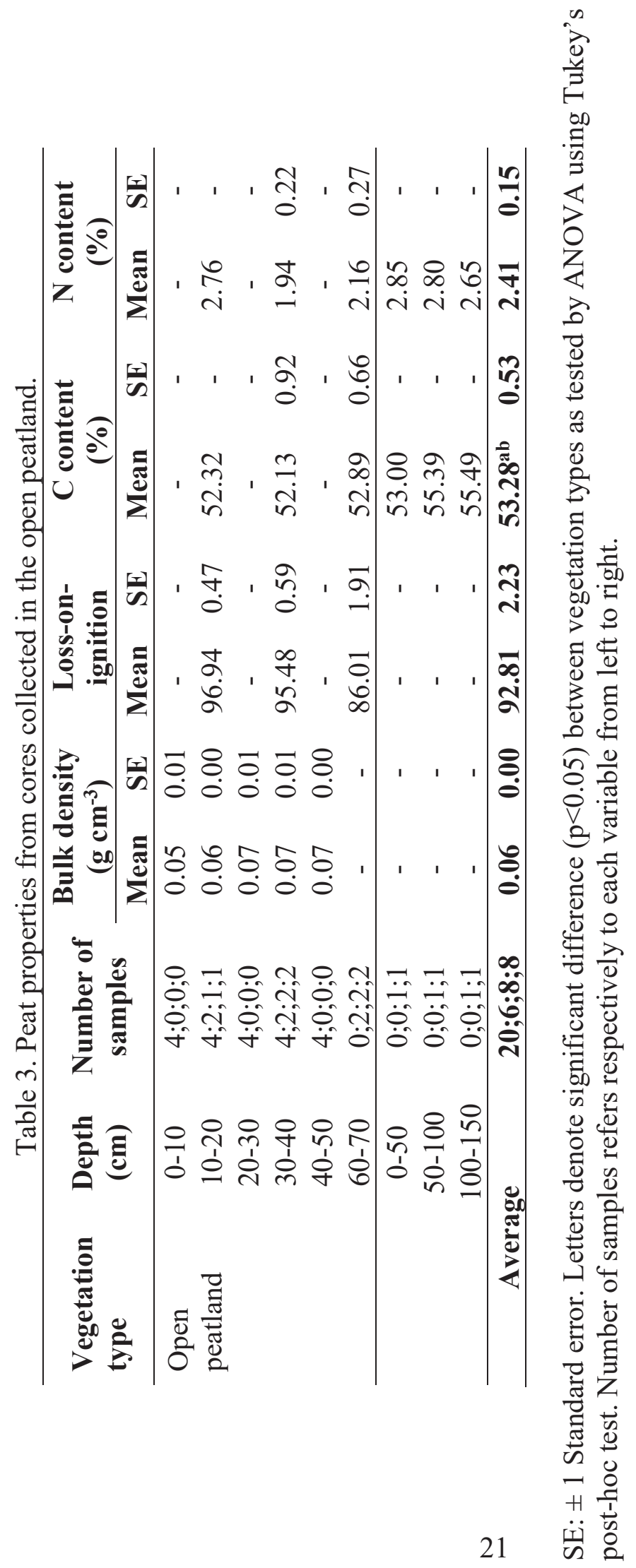




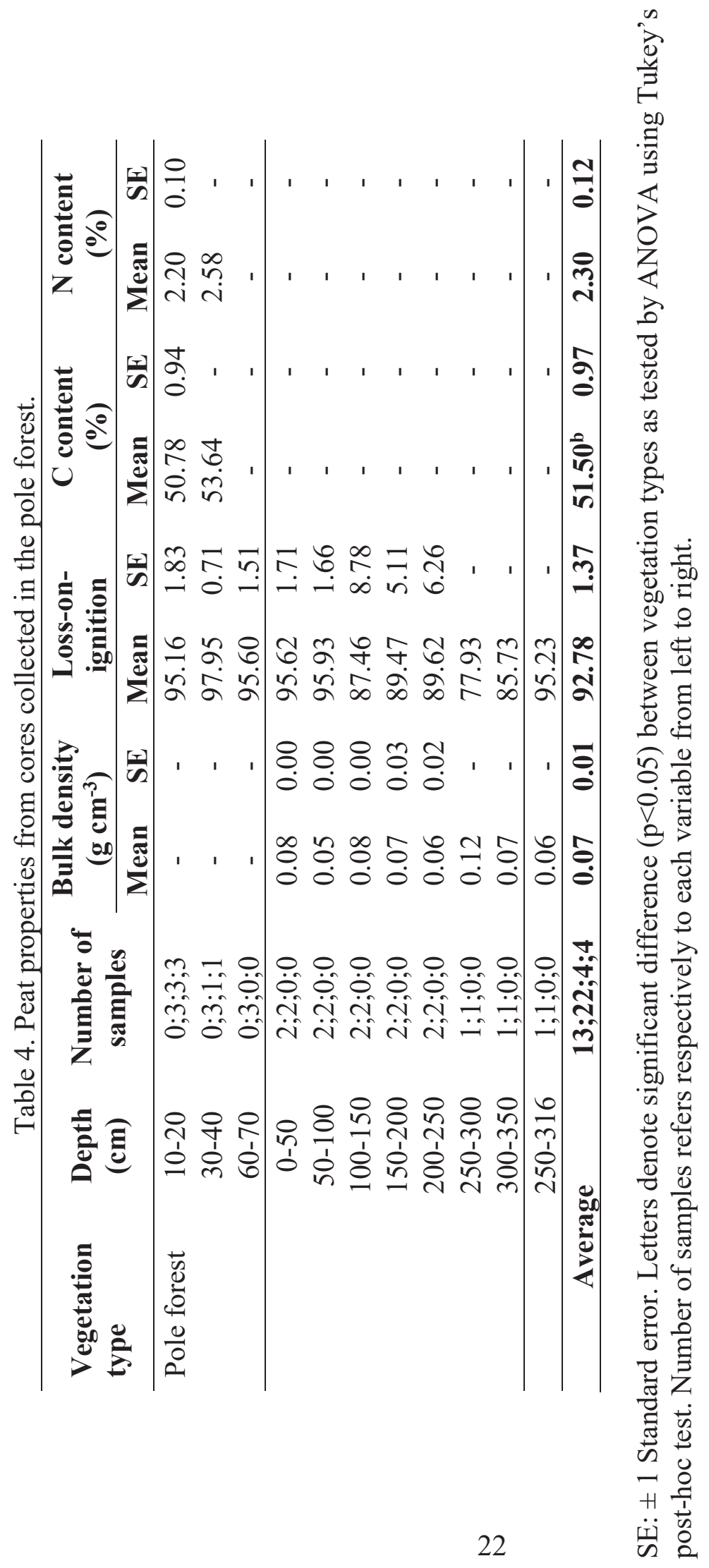




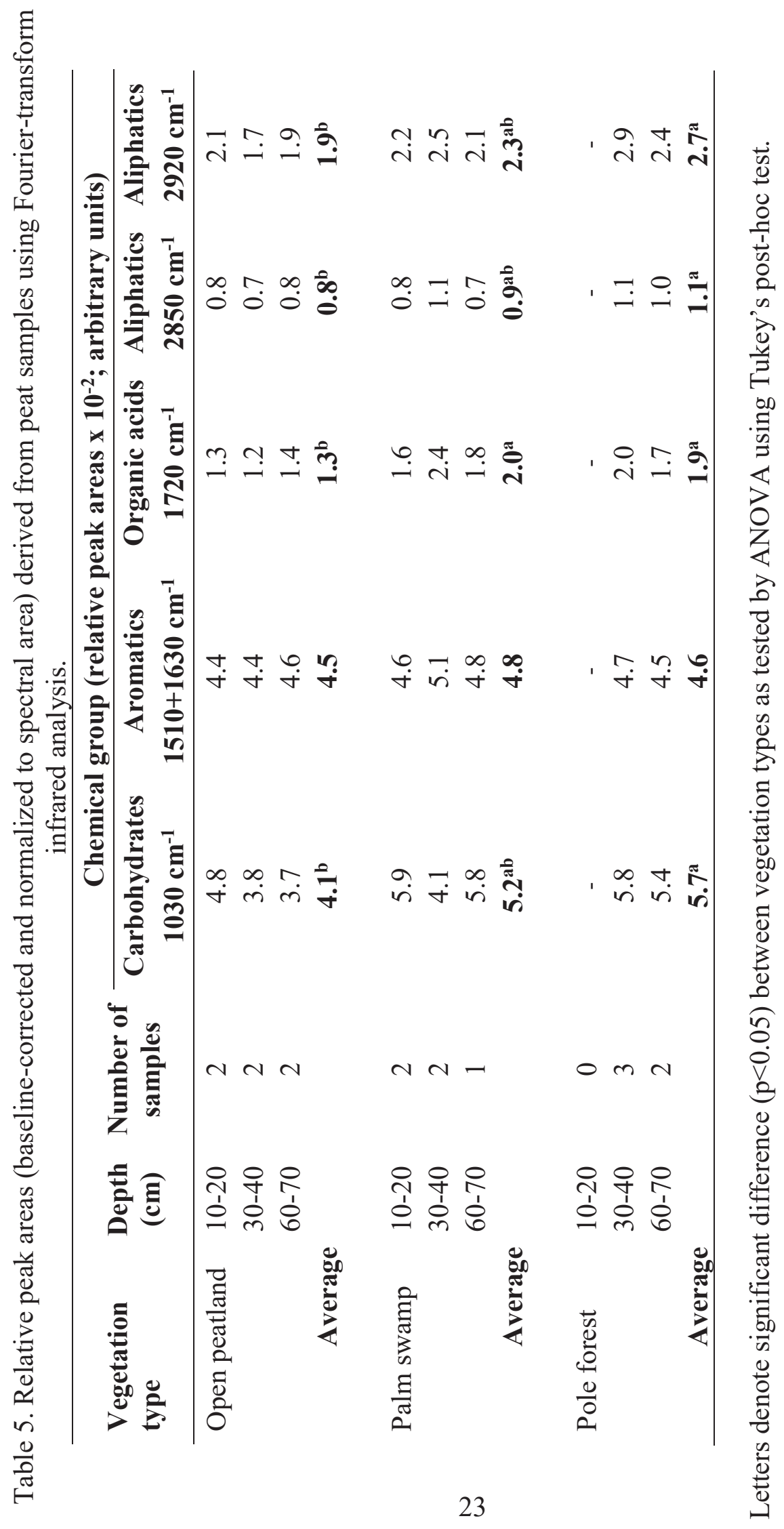


Table 6. Water chemistry $\left(\mathrm{mg} \mathrm{L}^{-1}\right)$ of porewater from vegetation types.

\begin{tabular}{lcccccc} 
& \multicolumn{6}{c}{ Vegetation type } \\
\cline { 2 - 7 } Cation & \multicolumn{2}{c}{ Open peatland } & \multicolumn{2}{c}{ Palm swamp } & \multicolumn{2}{c}{ Pole forest } \\
\cline { 2 - 7 } & \multicolumn{1}{c}{ Mean } & SE & Mean & SE & Mean & SE \\
\hline $\mathrm{Ca}^{+2}$ & $2.928^{\mathrm{a}}$ & 0.279 & $4.679^{\mathrm{a}}$ & 0.742 & $0.425^{\mathrm{b}}$ & 0.028 \\
$\mathrm{Mg}^{+2}$ & $0.263^{\text {ab }}$ & 0.010 & $0.510^{\mathrm{a}}$ & 0.132 & $0.137^{\mathrm{b}}$ & 0.019 \\
$\mathrm{Fe}^{+3}$ & 0.225 & 0.052 & 0.264 & 0.056 & 0.342 & 0.066 \\
$\mathrm{~K}^{+}$ & 0.634 & 0.116 & 1.212 & 0.342 & 1.043 & 0.185 \\
$\mathrm{Na}^{+}$ & 1.537 & 0.175 & 2.258 & 0.245 & 1.501 & 0.340 \\
$\mathrm{Ni}^{+2}$ & 0.005 & 0.000 & 0.014 & 0.006 & 0.010 & 0.001 \\
$\mathrm{Cu}^{+2}$ & 0.011 & 0.004 & 0.020 & 0.008 & 0.008 & 0.002 \\
$\mathrm{Ca}^{+2} / \mathrm{Mg}^{+2}$ & $11.190^{\mathrm{a}}$ & 1.163 & $10.046^{\mathrm{a}}$ & 0.883 & $3.425^{\mathrm{b}}$ & 0.442 \\
\hline
\end{tabular}

Letters denote significant difference $(\mathrm{p}<0.05)$ between vegetation types as tested by ANOVA using Tukey's post-hoc test. SE: \pm 1 Standard error. 


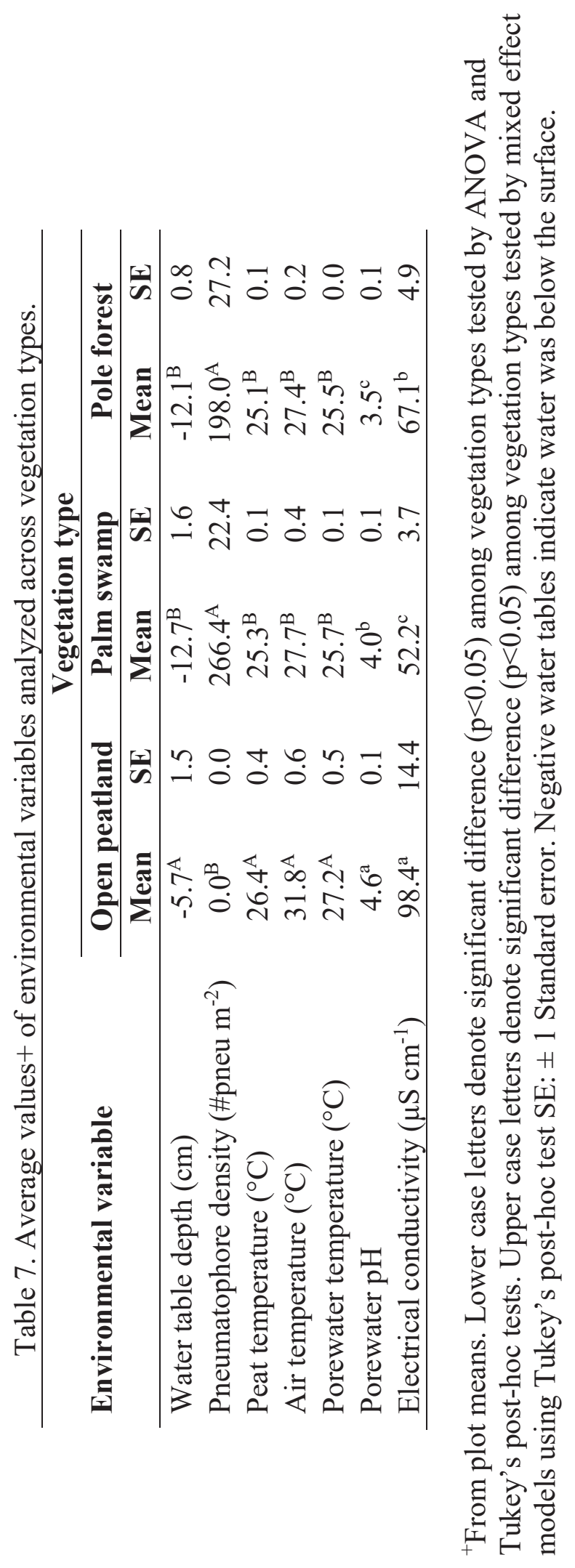




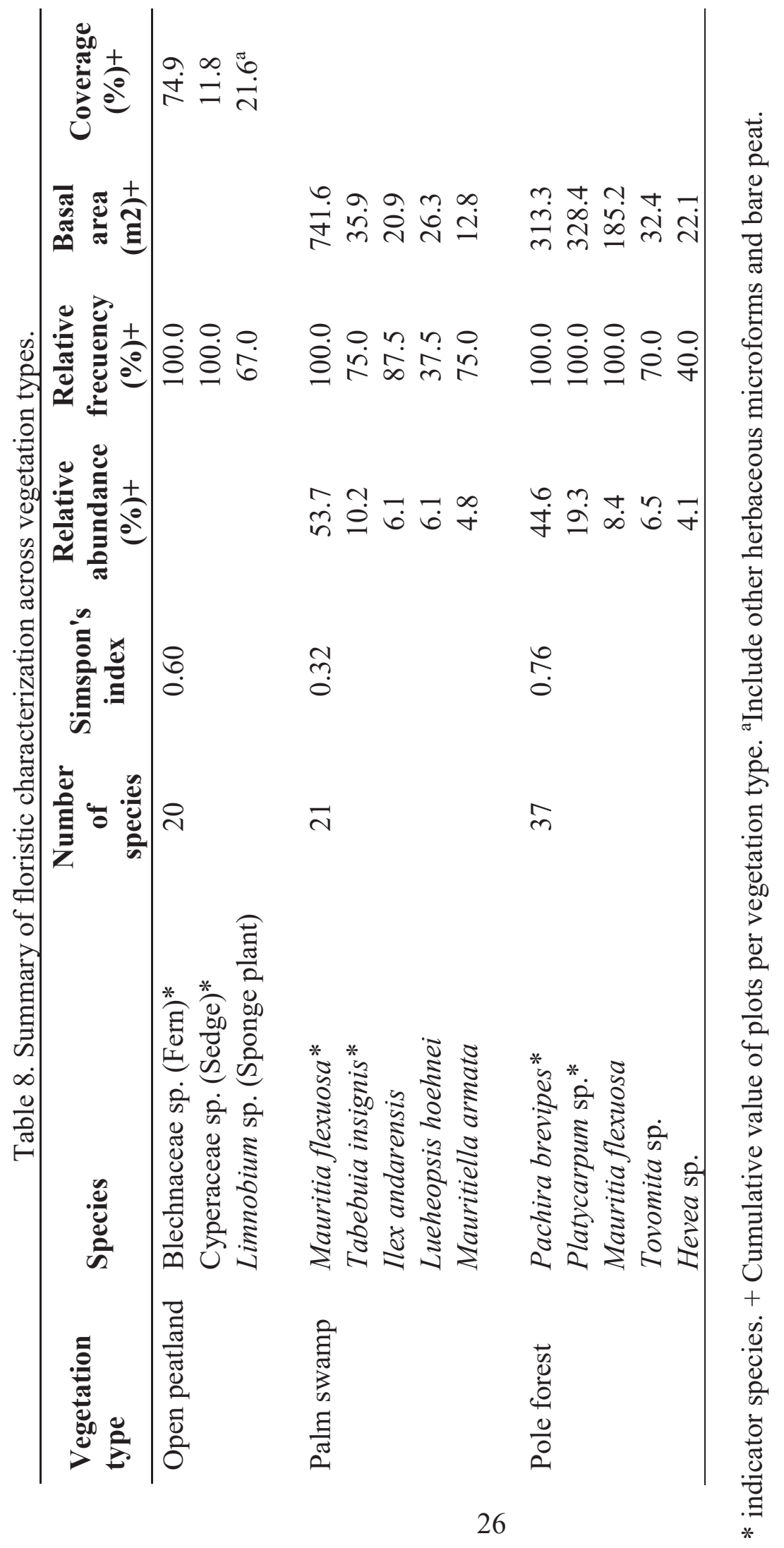


Table 9. Pearson $\left(r, r^{2}\right)$ and Kendall ranked (tau) correlations of environmental variables/porewater chemistry with NMS ordination axes.

\begin{tabular}{|c|c|c|c|c|c|c|}
\hline \multirow{2}{*}{$\begin{array}{l}\text { Environmental } \\
\text { variables }\end{array}$} & \multicolumn{3}{|c|}{ Axis 1} & \multicolumn{3}{|c|}{ Axis 2} \\
\hline & $\mathbf{r}$ & $\mathbf{r}^{2}$ & tau & $\mathbf{r}$ & $\mathbf{r}^{2}$ & tau \\
\hline Water table depth & 0.68 & 0.46 & 0.42 & 0.44 & 0.19 & 0.40 \\
\hline $\mathrm{pH}$ & 0.60 & 0.35 & 0.41 & 0.75 & 0.56 & 0.41 \\
\hline Electrical conductivity & 0.60 & 0.36 & 0.33 & 0.06 & 0.00 & -0.01 \\
\hline $\mathrm{Ca}^{+2}$ & -0.28 & 0.08 & -0.11 & 0.85 & 0.72 & 0.58 \\
\hline $\mathrm{Mg}^{+2}$ & -0.40 & 0.16 & -0.15 & 0.60 & 0.36 & 0.56 \\
\hline $\mathrm{Fe}^{+3}$ & -0.07 & 0.01 & -0.03 & -0.38 & 0.14 & -0.33 \\
\hline $\mathrm{K}^{+}$ & -0.52 & 0.27 & -0.49 & -0.02 & 0.00 & 0.01 \\
\hline $\mathrm{Na}^{+}$ & -0.32 & 0.10 & -0.28 & 0.35 & 0.12 & 0.64 \\
\hline $\mathrm{Ni}^{+2}$ & -0.49 & 0.24 & -0.35 & 0.03 & 0.00 & -0.25 \\
\hline $\mathrm{Cu}^{+2}$ & -0.34 & 0.12 & -0.17 & 0.38 & 0.14 & 0.13 \\
\hline
\end{tabular}

Table 10. Average soil gas fluxes (all data) by vegetation type.

\begin{tabular}{|c|c|c|c|c|c|c|c|c|c|c|}
\hline \multirow{2}{*}{$\begin{array}{l}\text { Vegetation } \\
\text { type }\end{array}$} & \multirow{2}{*}{$\begin{array}{c}\text { Plots } \\
\text { and } \\
\text { collars }\end{array}$} & \multicolumn{3}{|c|}{$\begin{array}{c}\text { Soil CH}_{4} \text { flux } \\
\left(\mathrm{mg} \mathrm{m}^{-2} \mathbf{d}^{-1}\right)\end{array}$} & \multicolumn{3}{|c|}{$\begin{array}{l}\text { Soil } \mathrm{CO}_{2} \text { flux } \\
\quad\left(\mathrm{g} \mathrm{m}^{-2} \mathrm{~d}^{-1}\right)\end{array}$} & \multicolumn{3}{|c|}{ Soil $\mathrm{CO}_{2} / \mathrm{CH}_{4}$} \\
\hline & & Mean & SE & $\mathbf{n}$ & Mean & SE & $\mathbf{n}$ & & SE & $\mathbf{n}$ \\
\hline & $10 ; 20$ & 64.7 & 8.8 & 145 & 11.4 & 1.2 & 143 & & 77.6 & 135 \\
\hline Palm swamp & $9 ; 17$ & 72.7 & 5.4 & 129 & 16.2 & 2.1 & 133 & 400.6 & 108.5 & 129 \\
\hline
\end{tabular}

Table 11. Ecosystem $\mathrm{CH}_{4}$ fluxes from different plant types in the open peatland.

\begin{tabular}{|c|c|c|c|c|}
\hline \multirow{2}{*}{ Plant type } & \multirow{2}{*}{$\begin{array}{l}\text { Plots } \\
\text { and } \\
\text { collars }\end{array}$} & \multicolumn{3}{|c|}{$\begin{array}{l}\text { Ecosystem } \mathrm{CH}_{4} \text { flux } \\
\left(\mathrm{mg} \mathrm{m}^{-2} \mathrm{~d}^{-1}\right)\end{array}$} \\
\hline & & Mean & SE & $\mathbf{n}$ \\
\hline Sponge plant* & $5 ; 5$ & 72.2 & 26.6 & 35 \\
\hline Fern & $3 ; 3$ & 12.2 & 13.0 & 17 \\
\hline Sedge & $3 ; 3$ & 127.6 & 18.9 & 22 \\
\hline Open peatland & $6 ; 11$ & 74.9 & 14.8 & 74 \\
\hline
\end{tabular}

* Include bare soil 
Table 12. Repeated measures mixed effect model analyzing soil $\mathrm{CH}_{4}$ fluxes* from the treed peatlands (Model 1).

\begin{tabular}{lcccc}
\hline Effect & $\begin{array}{c}\text { Numerator } \\
\text { df }\end{array}$ & $\begin{array}{c}\text { Denominator } \\
\text { df }\end{array}$ & $\begin{array}{c}\text { F- } \\
\text { value }\end{array}$ & $\begin{array}{c}\text { p- } \\
\text { value }\end{array}$ \\
\hline Vegetation & 1 & 66.96 & 0.60 & 0.4428 \\
Microtopography & 1 & 66.96 & 0.26 & 0.6111 \\
Vegetation x Microtopography & 1 & 66.96 & 0.41 & 0.5222 \\
Date & 7 & 68.76 & 2.83 & $\mathbf{0 . 0 1 1 8}$ \\
Vegetation x Date & 7 & 68.76 & 0.94 & 0.4851 \\
Microtopography x Date & 7 & 68.76 & 1.04 & 0.4147 \\
Vegetation x Microtopography x Date & 7 & 68.76 & 1.06 & 0.4000 \\
\hline
\end{tabular}

* Exclude fluxes from the open peatland. Significant effects are in bold $(p<0.05)$.

Table 13. Repeated measures mixed effect model analyzing log-transformed ecosystem $\mathrm{CH}_{4}$ fluxes from the open peatland (Model 3).

\begin{tabular}{lcccc}
\hline Effect & $\begin{array}{c}\text { Numerator } \\
\text { df }\end{array}$ & $\begin{array}{c}\text { Denominator } \\
\text { df }\end{array}$ & $\begin{array}{c}\text { F- } \\
\text { value }\end{array}$ & $\begin{array}{c}\text { p- } \\
\text { value }\end{array}$ \\
\hline Plant type & 2 & 15.52 & 4.24 & $\mathbf{0 . 0 3 3 9}$ \\
Date & 7 & 13.54 & 1.42 & 0.2741 \\
Plant type x Date & 14 & 15.09 & 0.36 & 0.9694 \\
\hline
\end{tabular}

Significant effects are in bold $(\mathrm{p}<0.05)$. 


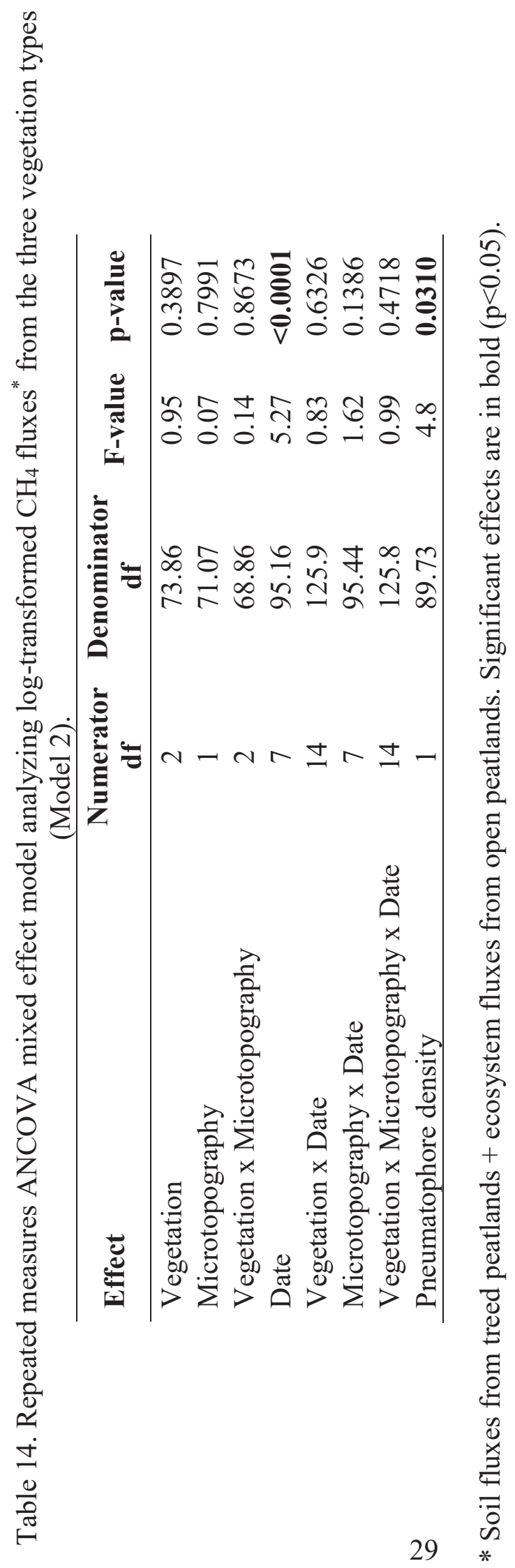




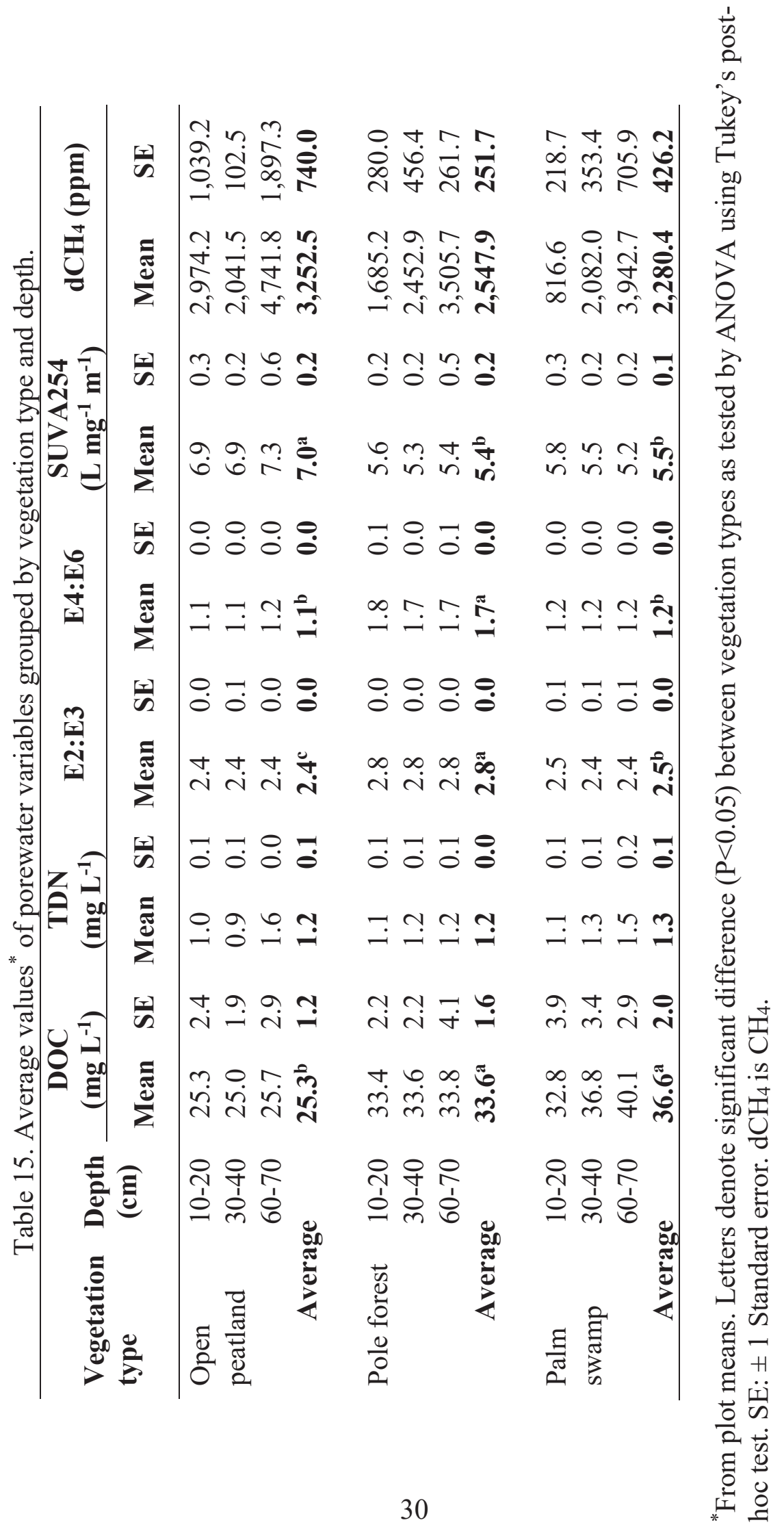


Table 16. Results from a repeated measures mixed effect model analyzing dissolved organic carbon concentration along the vegetation types and among peat depths.

\begin{tabular}{lcccc} 
Effect & $\begin{array}{c}\text { Numerator } \\
\text { df }\end{array}$ & $\begin{array}{c}\text { Denominator } \\
\text { df }\end{array}$ & F-value & p-value \\
\hline Vegetation & 2 & 38.14 & 6.94 & $\mathbf{0 . 0 0 2 7}$ \\
Depth & 2 & 30.64 & 0.48 & 0.6224 \\
Vegetation x Depth & 4 & 31.75 & 0.19 & 0.9433 \\
Date & 2 & 49.6 & 27.52 & $<\mathbf{0 . 0 0 0 1}$ \\
Vegetation x Date & 4 & 52.06 & 3.85 & $\mathbf{0 . 0 0 8 1}$ \\
Depth x Date & 4 & 52.16 & 0.71 & 0.5873 \\
Vegetation x Depth x Date & 8 & 53.49 & 1.99 & 0.0655 \\
\hline
\end{tabular}


Figures

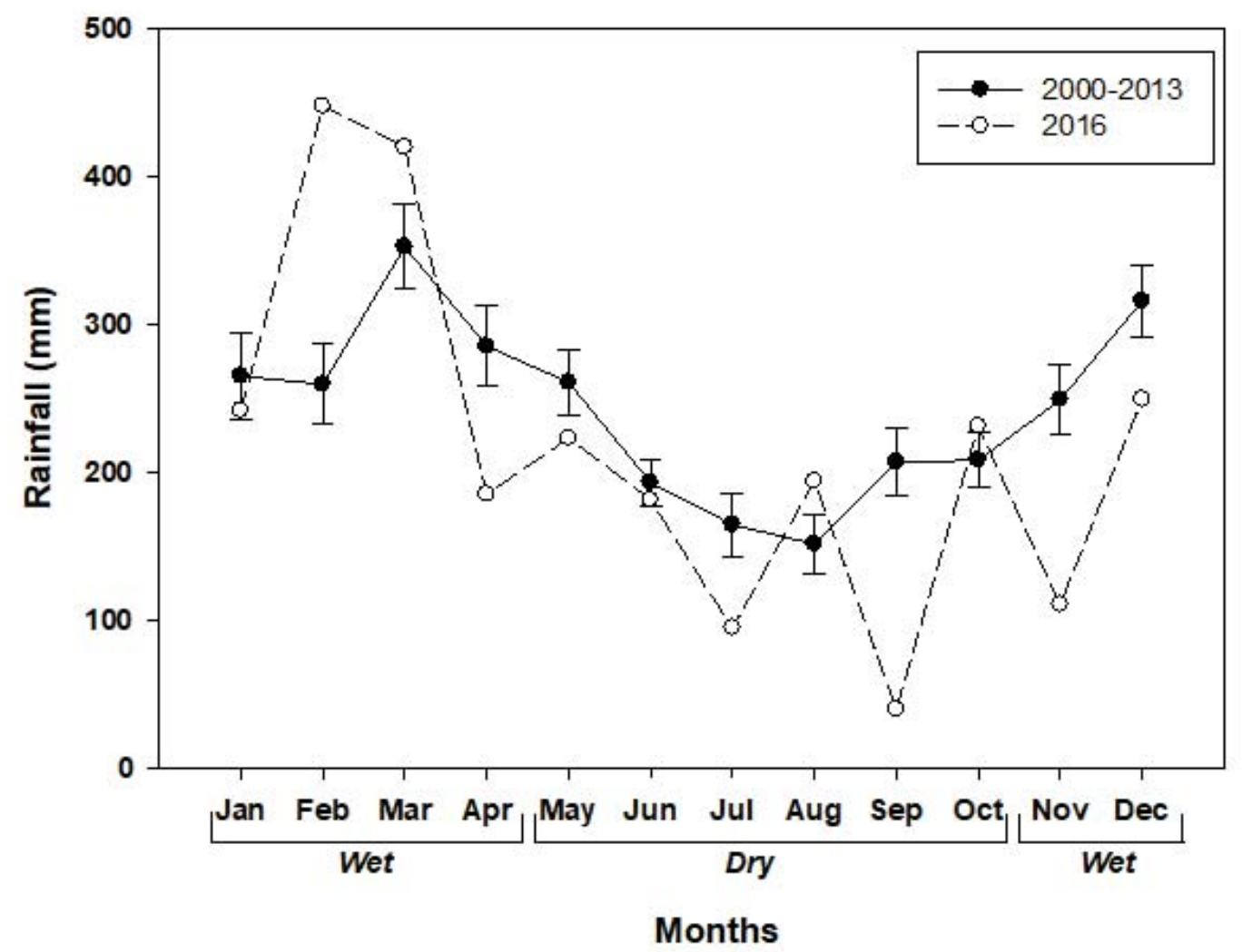

Figure 1. Rainfall patterns along period 2000-2013 and during the year of sampling. Wet and dry season are displayed. Data are means $1 \pm \mathrm{SE}$. 


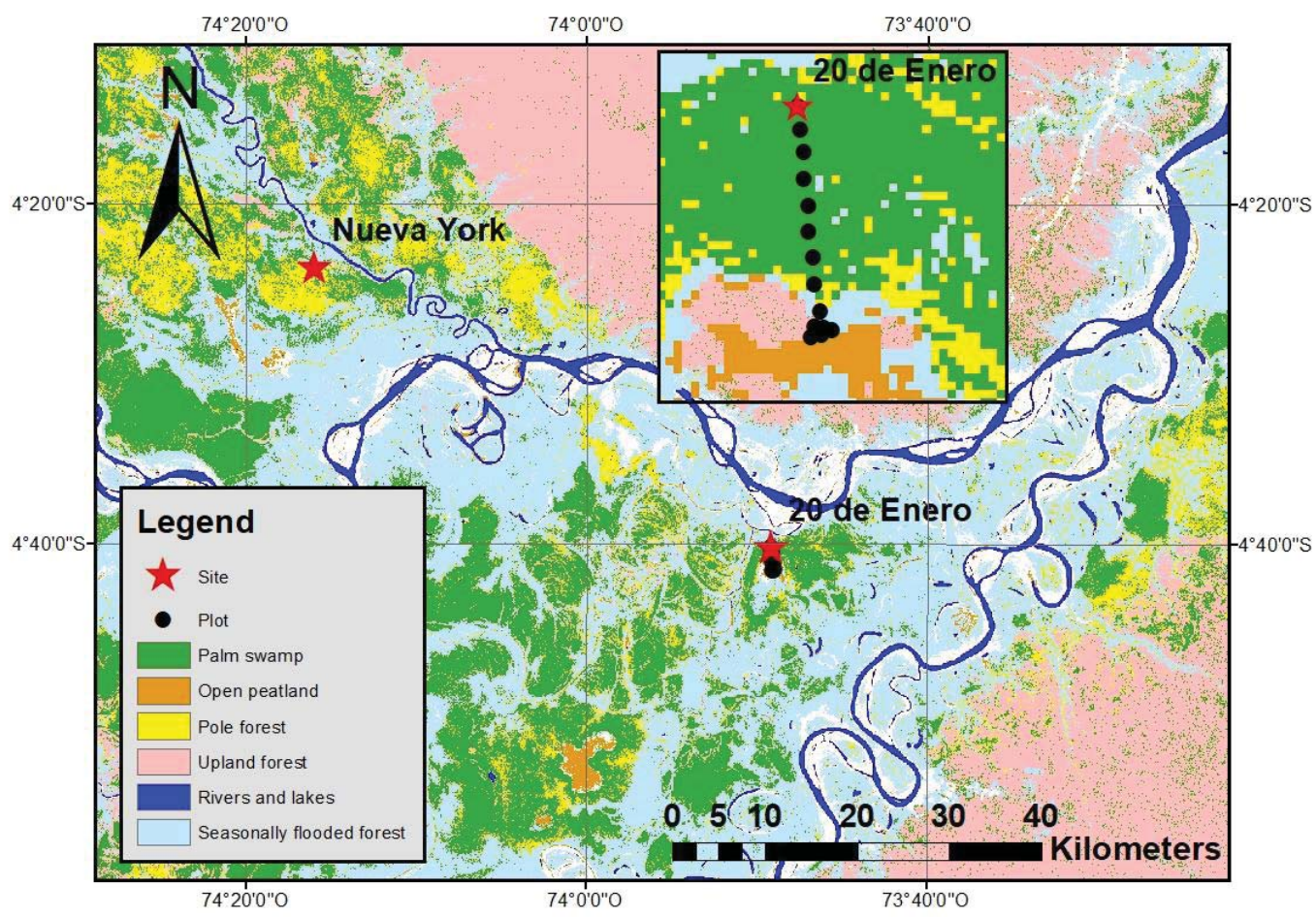

Figure 2. Map of PMB indicating the peatland sites (red stars). Mini map shows the transect in 20 de Enero site. 


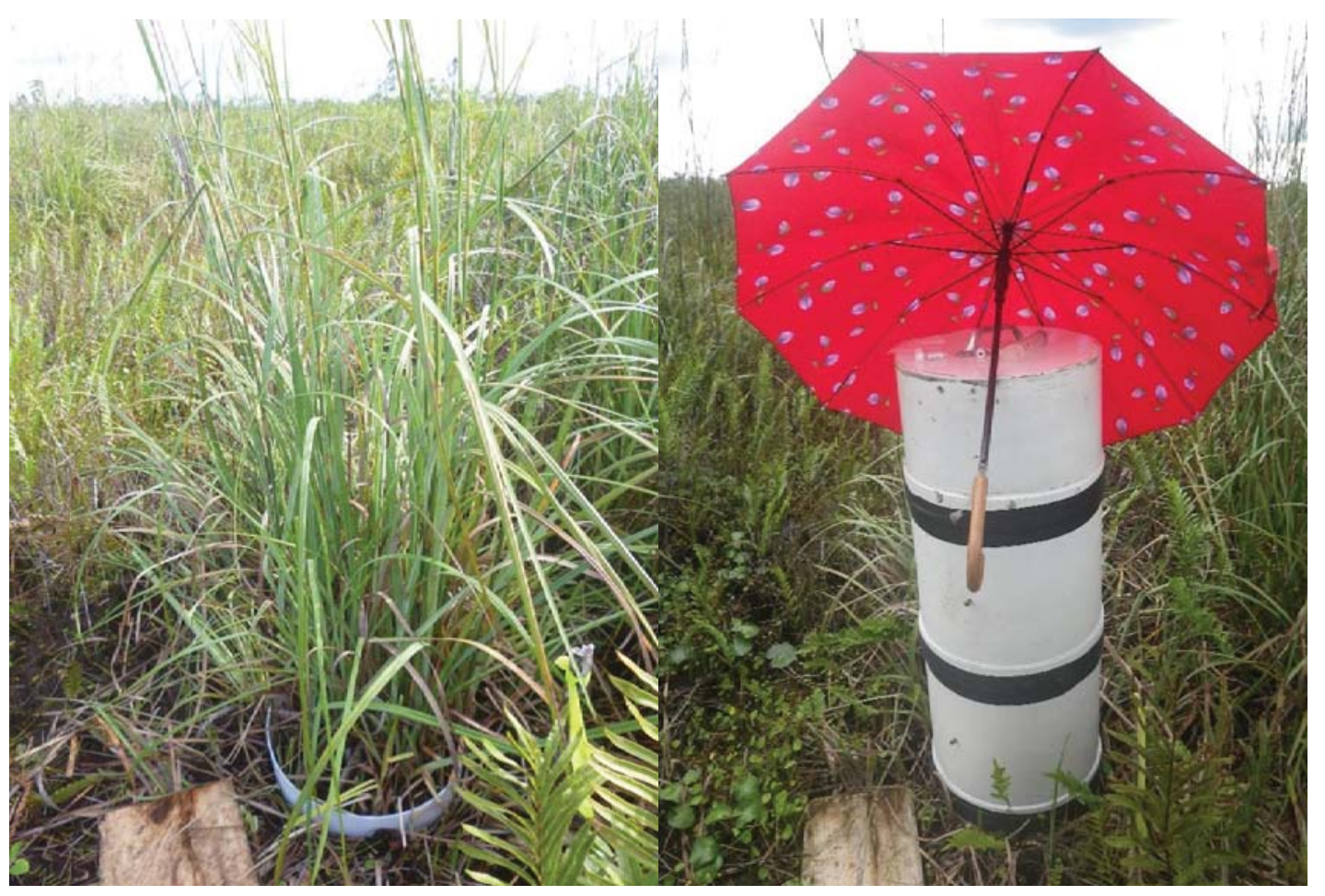

Figure 3. Collar surrounding the culm of sedges in the open peatland (left). PVC extensions used to measure ecosystem gas fluxes (right). 


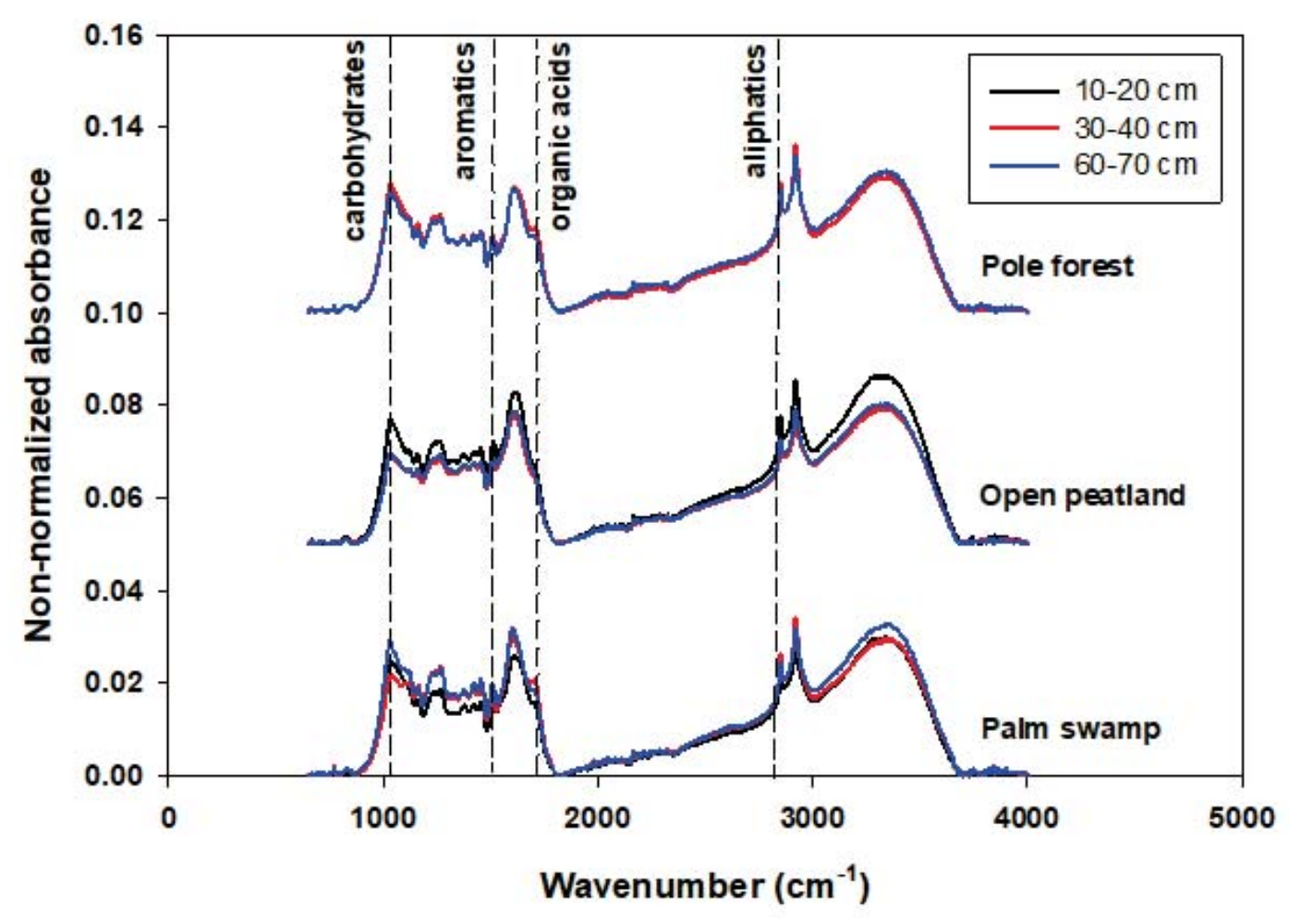

Figure 4. Mean non-normalized FTIR spectra of peat sampled at three different depths $(n=2)$, with open peatland and pole forest spectra stacked above (at 0.05 and 0.10 absorbance, respectively) palm swamp spectra for comparison. Vertical dashed lines indicate most of the wavenumbers where peaks were analyzed. 


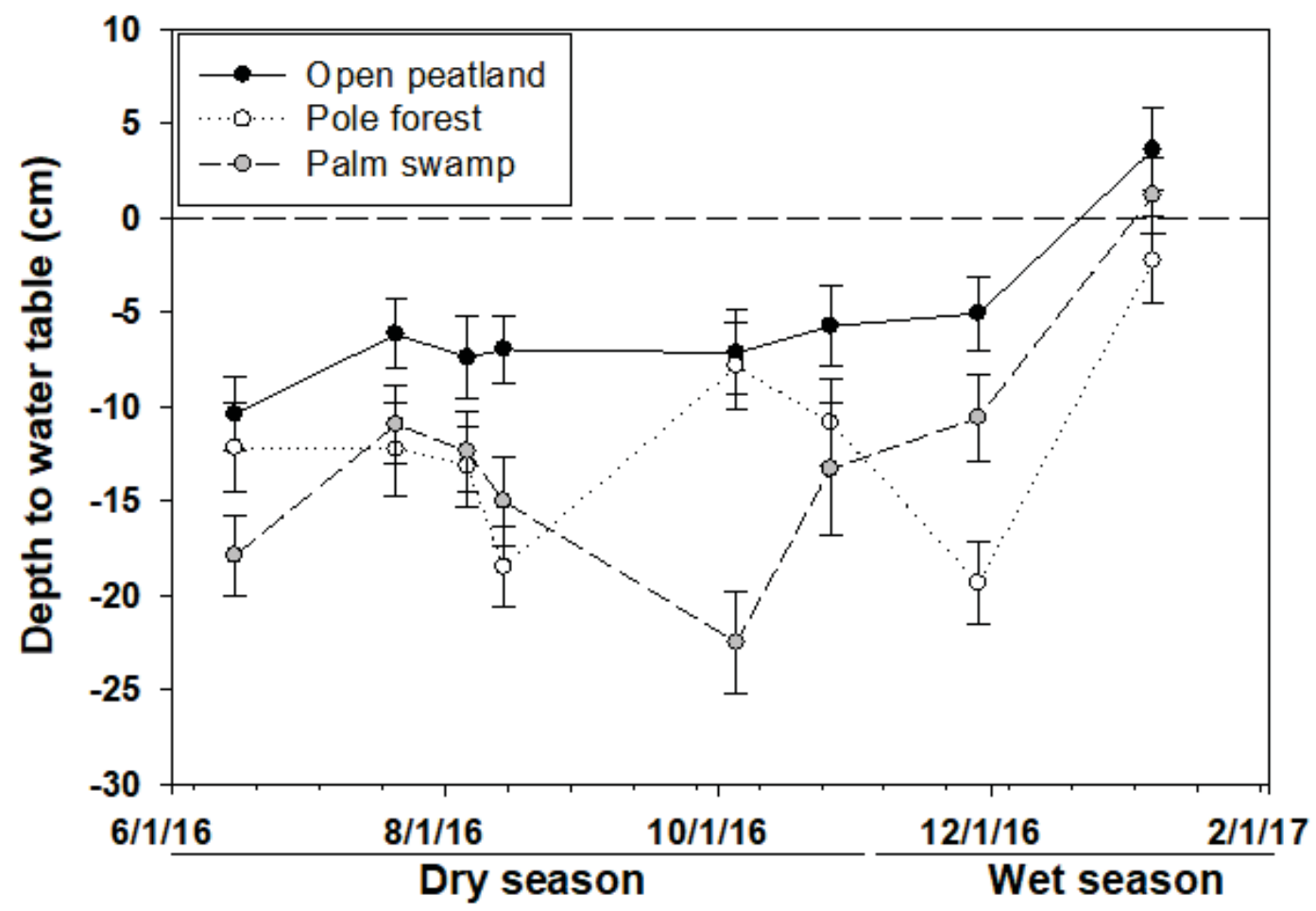

Figure 5. Water table depth changes by vegetation type along the sampling period. Symbols represent the average water table from all plots taken in that date. Dashed horizontal line indicates the peat surface. Positive water table indicates that surface was flooded. Error bars are $\pm 1 \mathrm{SE}$. 


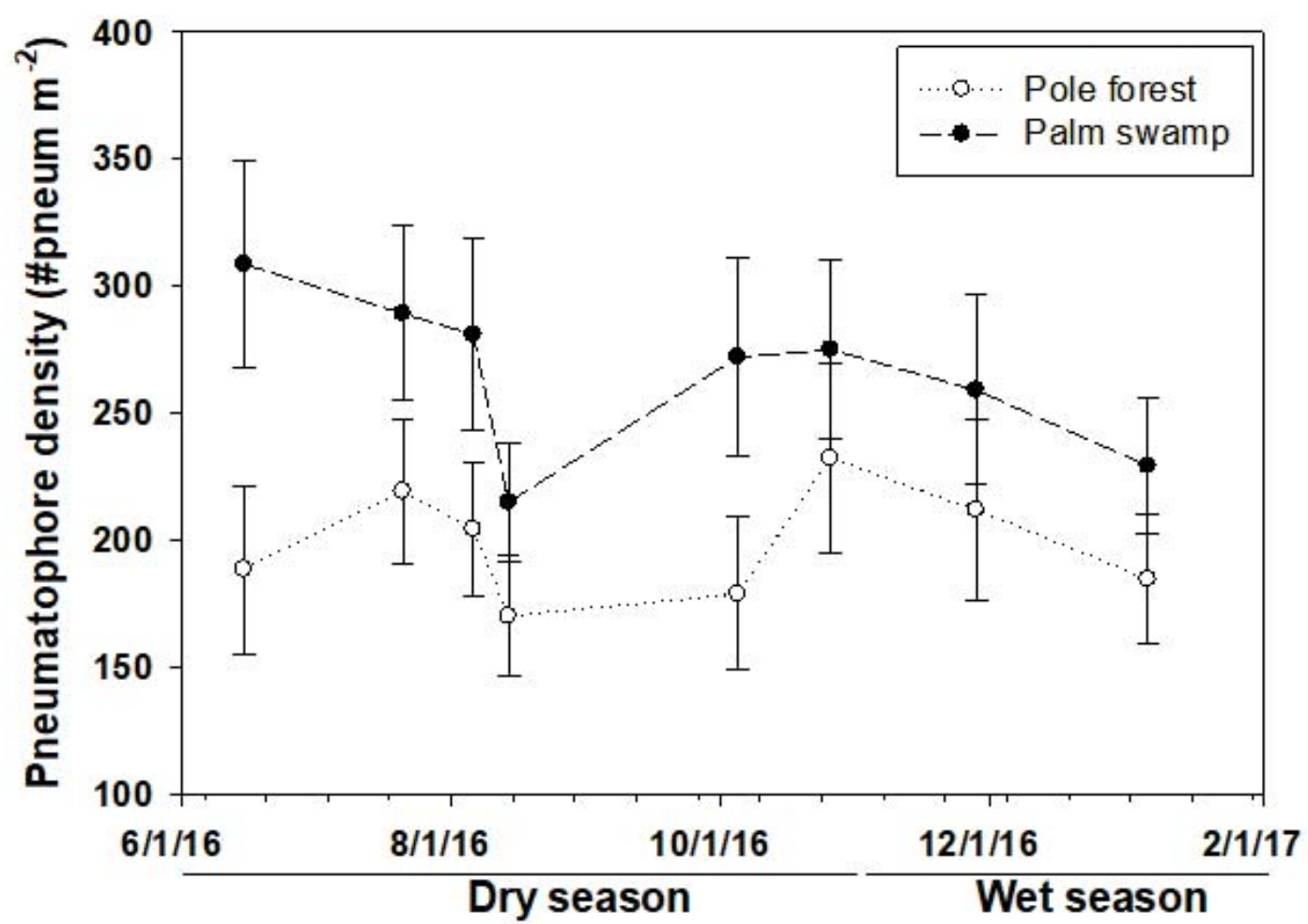

Figure 6. Pneumatophore density variation by vegetation type along the sampling period. Symbols represent the average density from all plots taken in that date. No pneumatophores were found in the open peatland. Error bars are $\pm 1 \mathrm{SE}$. 

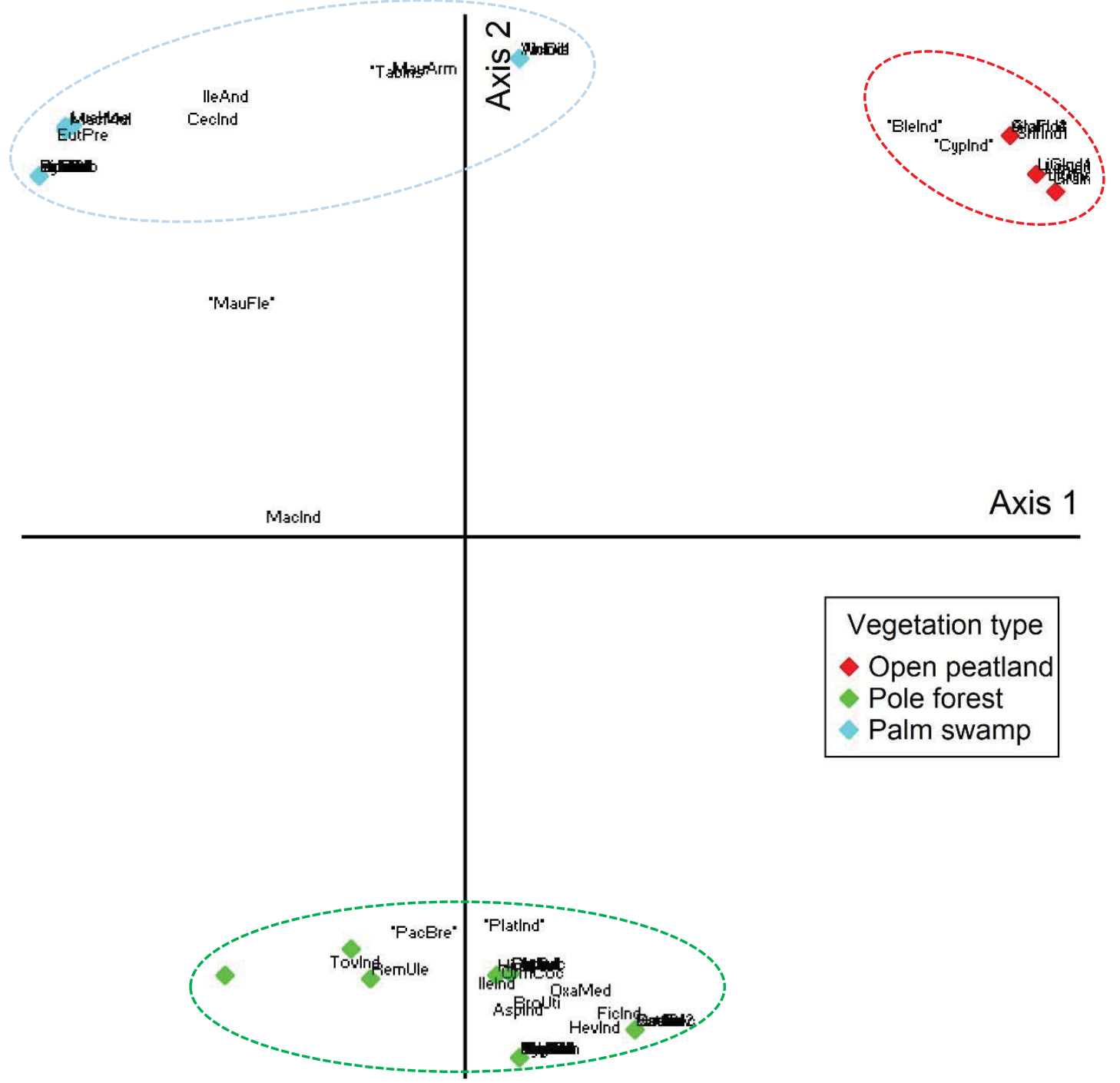

Figure 7. NMS diagram of plots and environmental vectors grouped by vegetation type. The first and second axes explain $49.4 \%$ and $43.1 \%$ respectively of the variation in the ordination. Cutoff $r^{2}$ value for vector is 0.30 . Circles around each vegetation type are for illustrative purposes. Species are included, and indicator species codes are enclosed by asterisks. MauFle: M. flexuosa, TabIns: T. insignis, CypInd: sedge, BleInd: fern, PacBre: $P$. brevipes, and PlatInd: Platycarpum sp. 


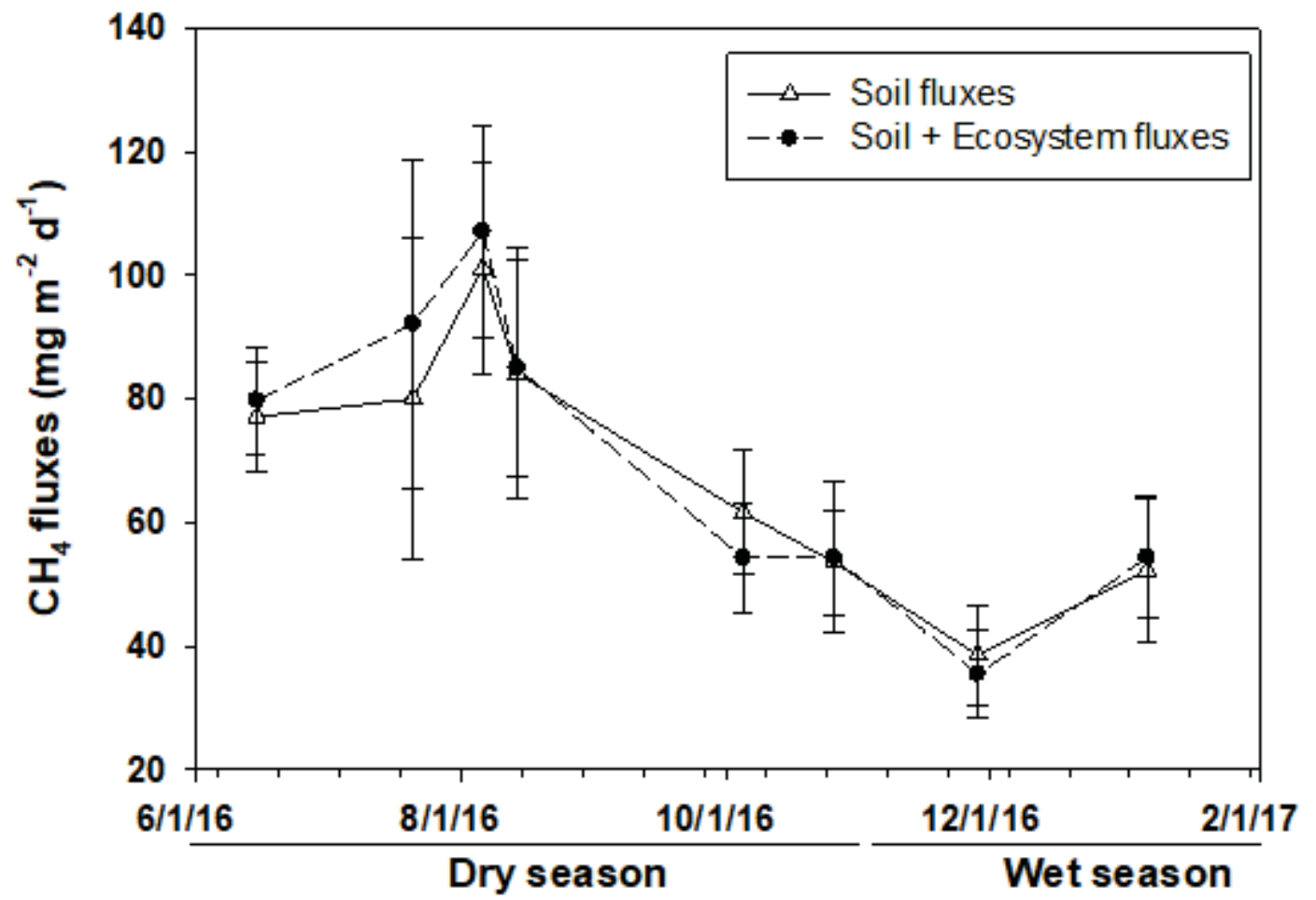

Figure 8. Methane fluxes variation by sampling date. Symbols represent the average flux from all plots taken in that date. Soil fluxes from treed peatlands and ecosystem fluxes from open peatlands. Error bars are $\pm 1 \mathrm{SE}$. 


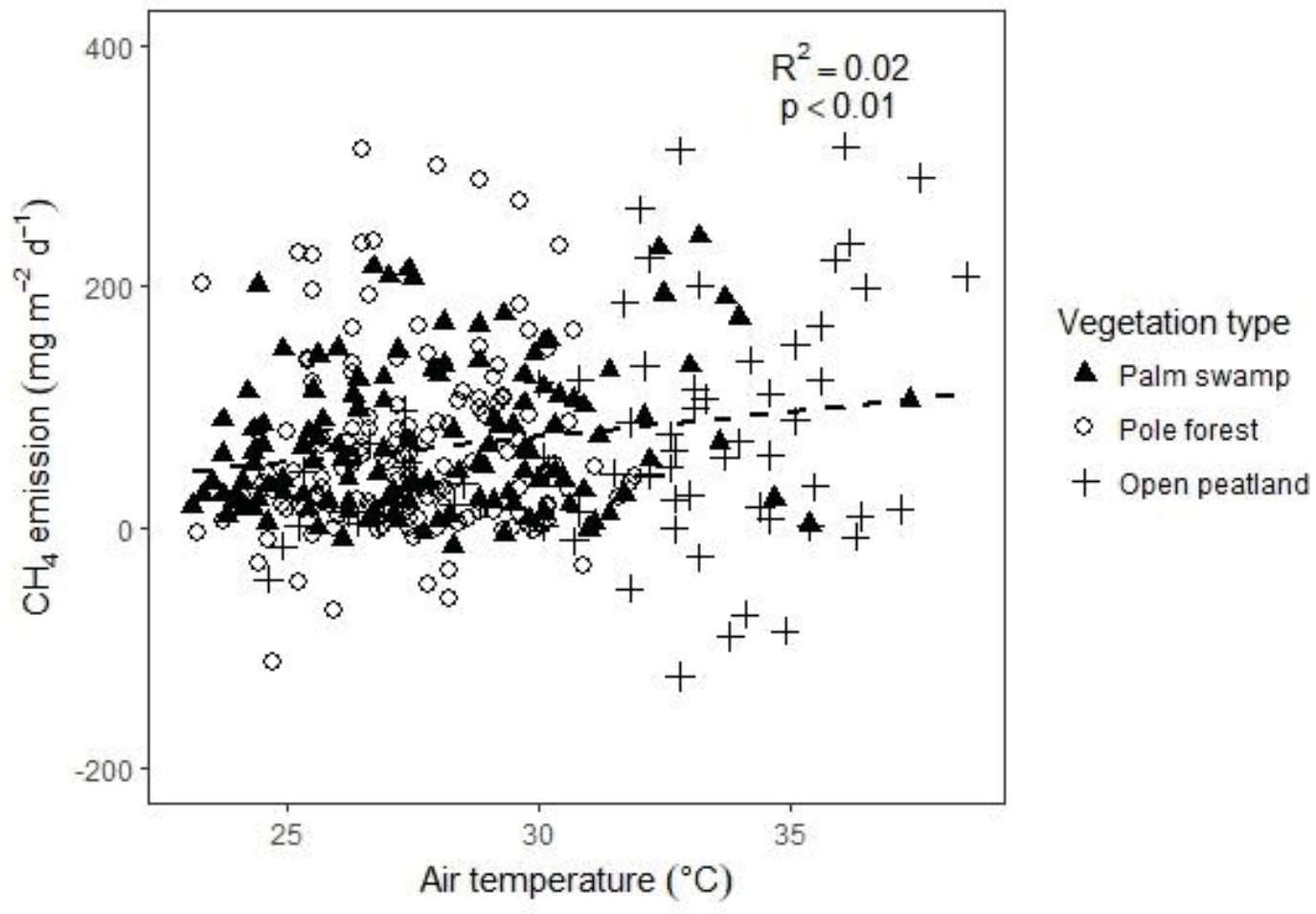

Figure 9. Association between air temperature (all data) and $\mathrm{CH}_{4}$ emissions (soil fluxes from treed peatland + ecosystem fluxes from open peatlands) grouped by vegetation type. Y-Axis scale was adjusted to better visualization, leaving some outliers out of plot ( $\mathrm{n}=3$ ). 


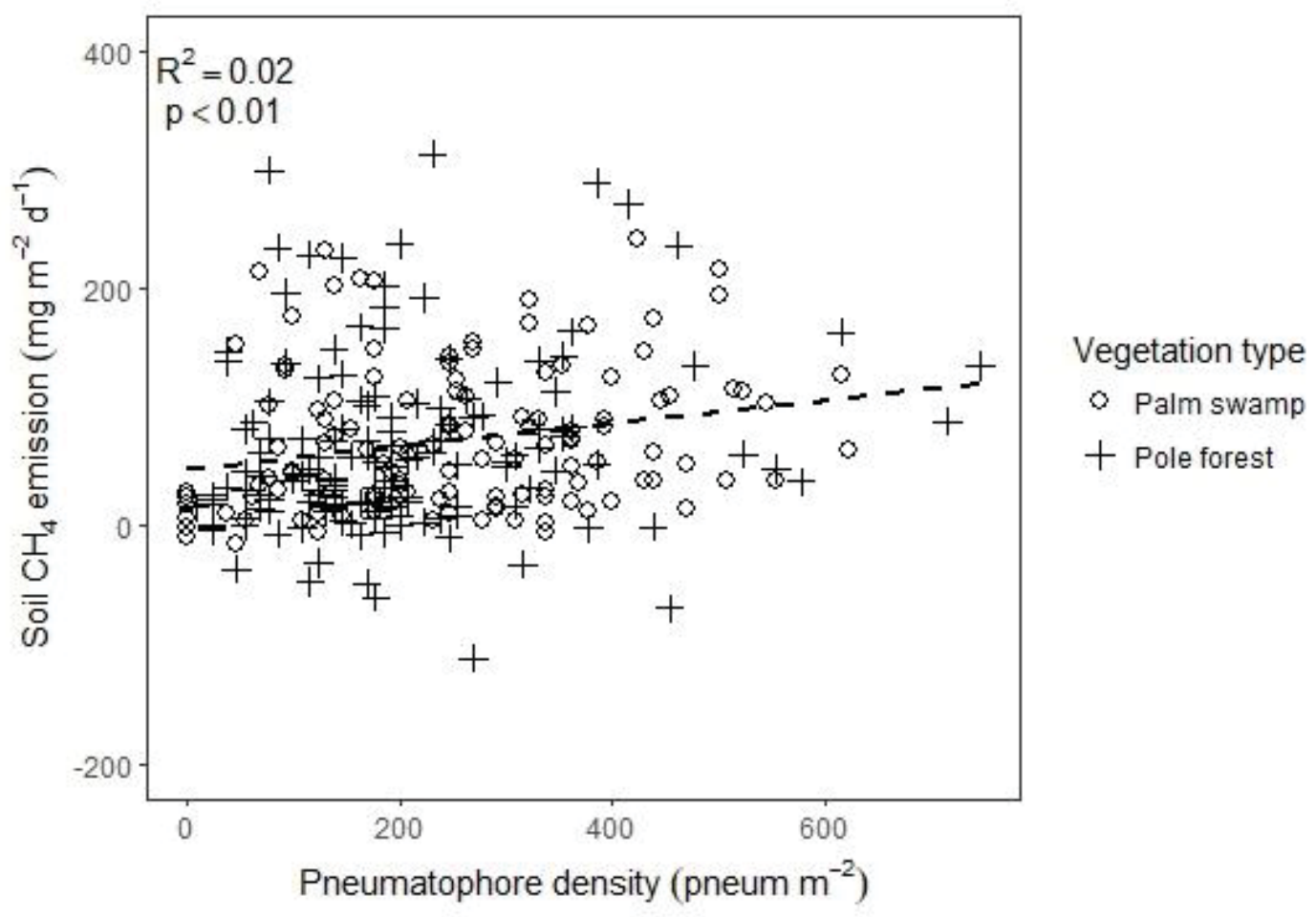

Figure 10. Association between pneumatophore density (all data) and soil $\mathrm{CH}_{4}$ emissions grouped by vegetation type. Y-Axis scale was adjusted to improve visualization, leaving one outlier out of plot. 


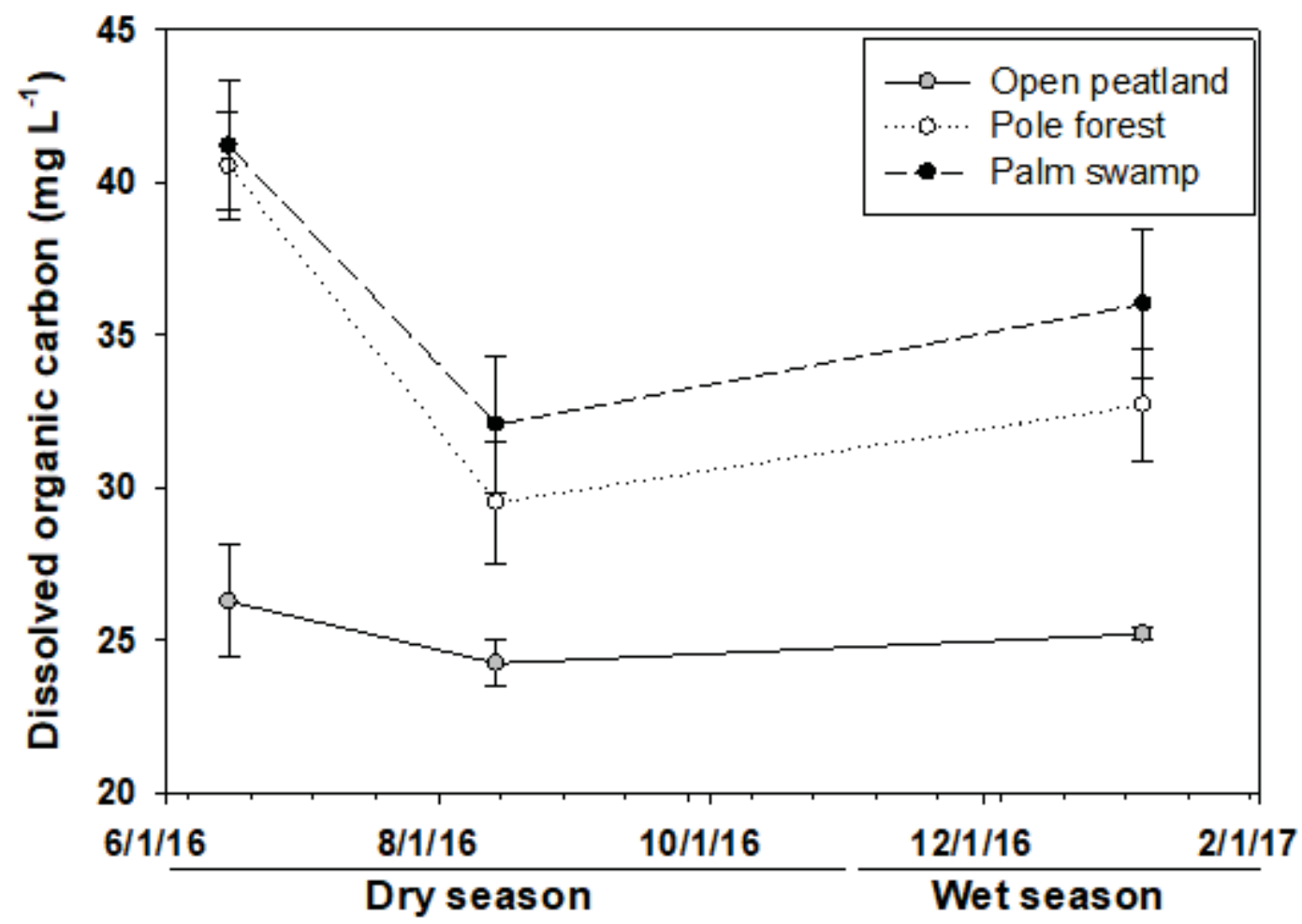

Figure 11. Variation of DOC concentration by vegetation type across the sampling period. Symbols represent the average concentration from all plots taken in that date. Error bars are $\pm 1 \mathrm{SE}$. 


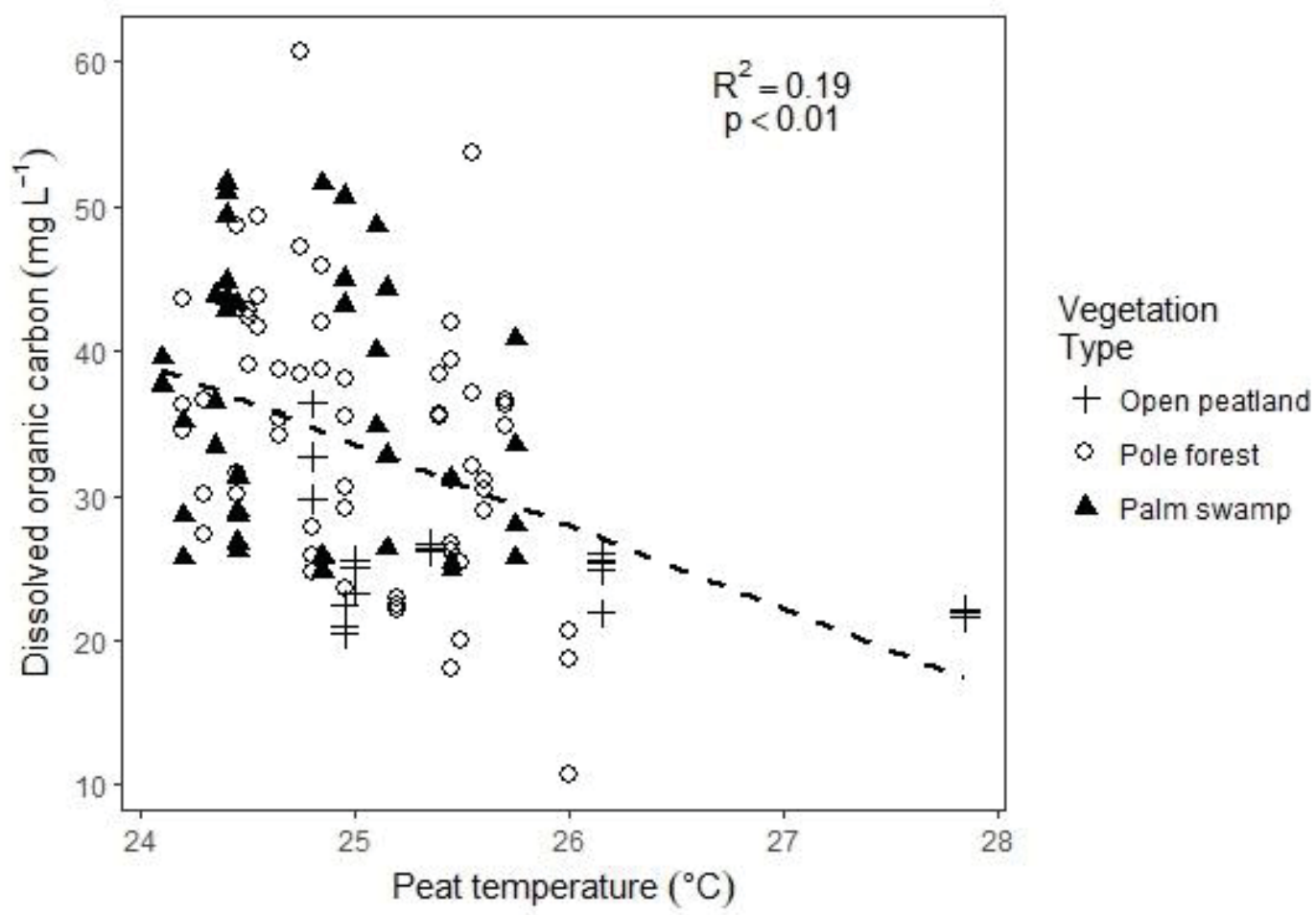

Figure 12. Association between all peat temperature data and DOC concentrations grouped by vegetation type. Peat temperature averages of hummocks and lawns were used for this analysis. 


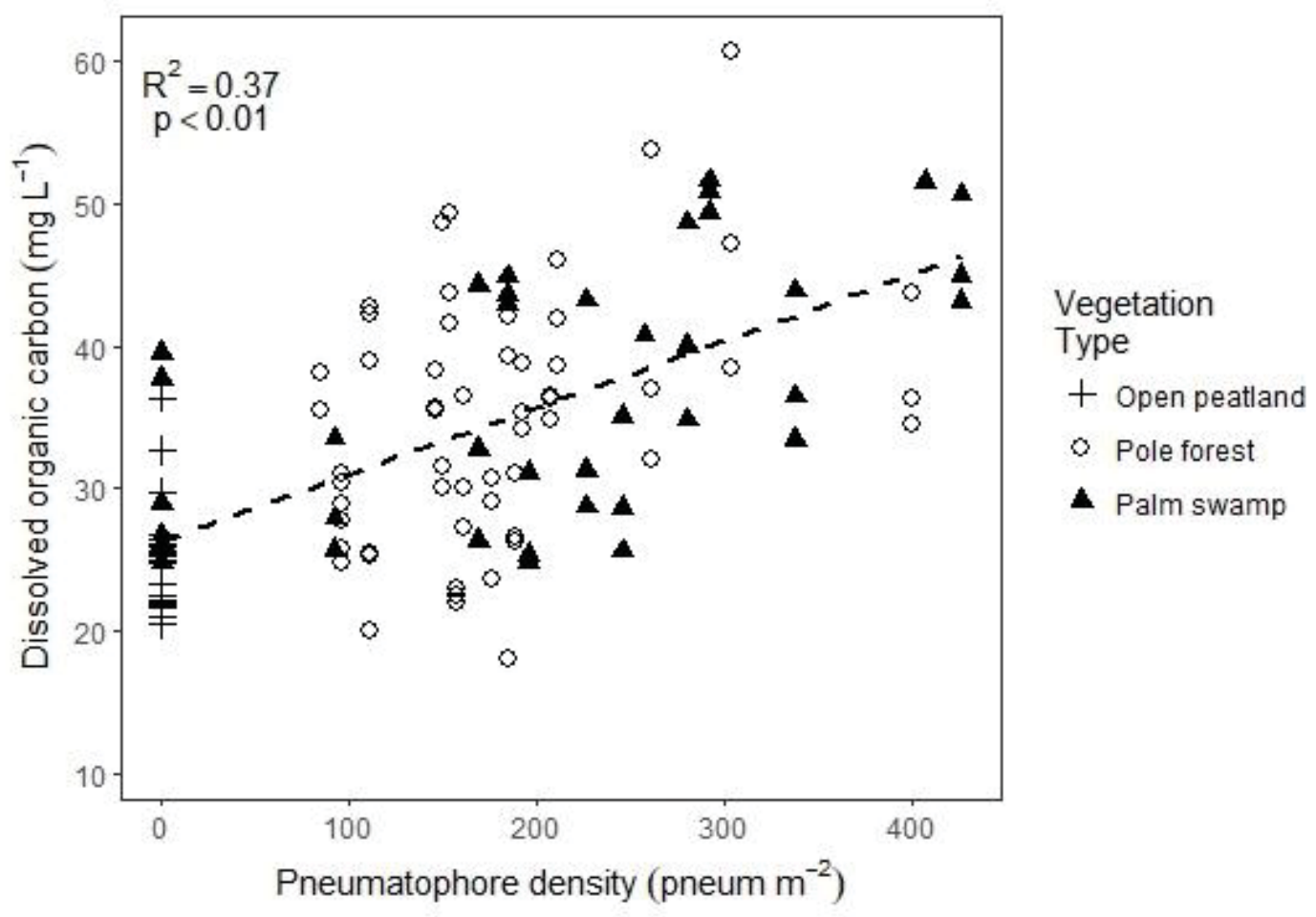

Figure 13. Association between all pneumatophore density data and DOC concentrations grouped by vegetation type. Pneumatophore density averages between hummocks and lawns were used for this analysis. 


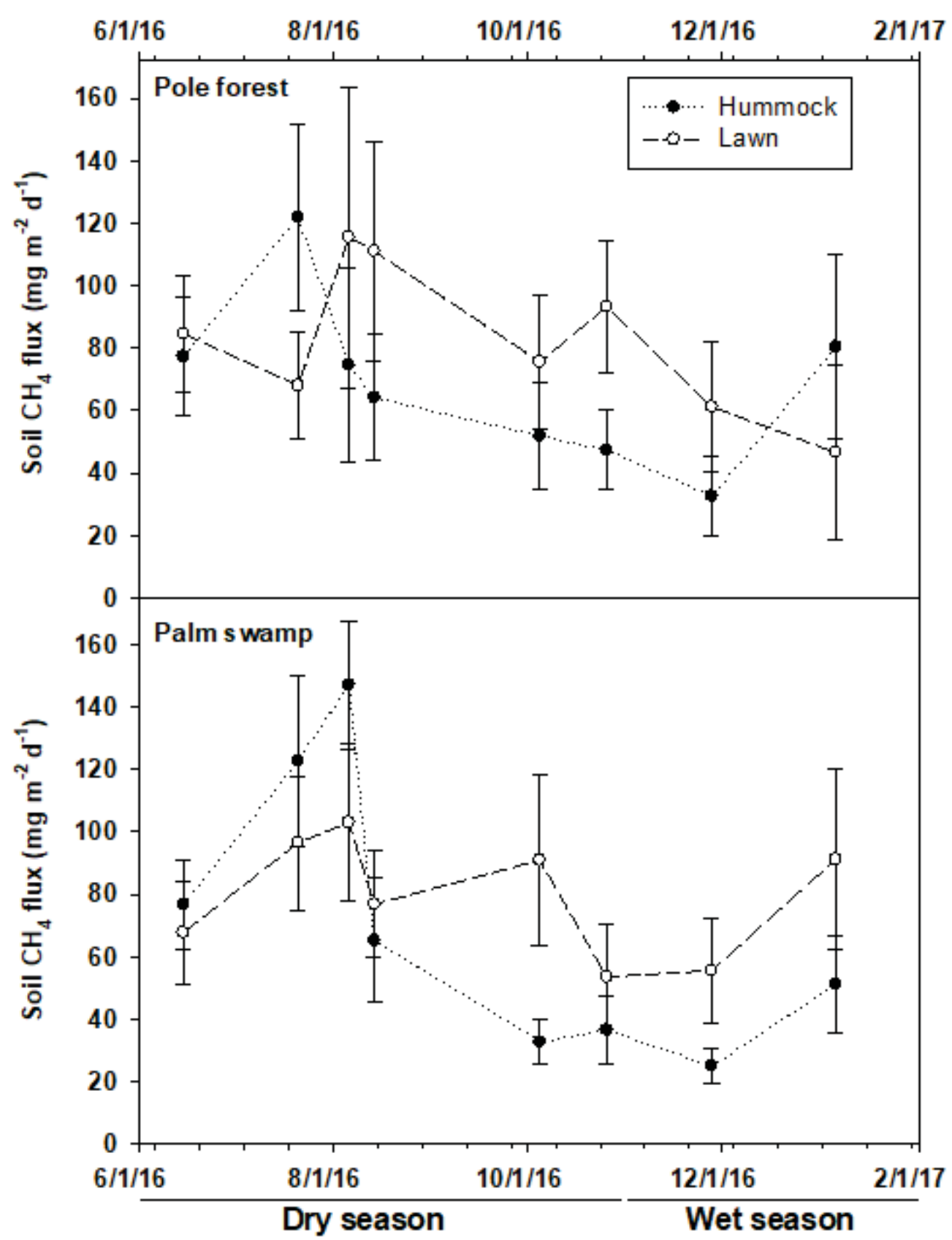

Figure 14. Temporal variation of soil methane fluxes grouped by vegetation type and microtopography. Symbols represent the average flux from all plots taken in that date. Error bars are $\pm 1 \mathrm{SE}$. 


\subsection{REFERENCE LIST}

1. Parish, F. et al. Assessment on Peatlands, Biodiversity and Climate Change: Main Report. (Global Environment Centre, Kuala Lumpur and Wetlands International, Wageningen, 2008). doi:10.1017/CBO9781107415324.004

2. Klepper, O. Model study of the Negara river basin to assess the regulating role of its wetlands. Regul. Rivers Res. Manag. 7, 311-325 (1992).

3. Page, S. E. et al. The amount of carbon released from peat and forest fires in Indonesia during 1997. Nature 420, 61-66 (2002).

4. Limpens, J. et al. Peatlands and the carbon cycle: from local processes to global implications - a synthesis. Biogeosciences 5, 1475-1491 (2008).

5. Page, S. E., Rieley, J. O. \& Banks, C. J. Global and regional importance of the tropical peatland carbon pool. Glob. Chang. Biol. 17, 798-818 (2011).

6. Dargie, G. C. et al. Age, extent and carbon storage of the central Congo Basin peatland complex. Nature 542, 86-90 (2017).

7. IPCC. Climate Change 2013: The Physical Science Basis. Contribution of Working Group I to the Fifth Assessment Report of the Intergovernmental Panel on Climate Change. (Cambridge University Press, 2013).

8. Turetsky, M. R. et al. A synthesis of methane emissions from 71 northern, temperate, and subtropical wetlands. Glob. Chang. Biol. 20, 2183-2197 (2014).

9. Mitsch, W. J. \& Gosselink, J. G. Wetlands. (John Wiley \& Sons, 2015).

10. Lawson, I. T. et al. Improving estimates of tropical peatland area, carbon storage, and greenhouse gas fluxes. Wetl. Ecol. Manag. 1-20 (2014). doi:10.1007/s11273-0149402-2

11. Jauhiainen, J., Takahashi, H., Heikkinen, J. E. P., Martikainen, P. J. \& Vasander, H. Carbon fluxes from a tropical peat swamp forest floor. Glob. Chang. Biol. 11, 17881797 (2005).

12. Page, S., Wust, R. \& Banks, C. Past and present carbon accumulation and loss in Southeast Asian peatlands. Pages News 18, 25-26 (2010).

13. Hergoualc'h, K. \& Verchot, L. V. Greenhouse gas emission factors for land use and land-use change in Southeast Asian peatlands. Mitig. Adapt. Strateg. Glob. Chang. 19, 789-807 (2014). 
14. Lähteenoja, O. et al. The large Amazonian peatland carbon sink in the subsiding Pastaza-Marañón foreland basin, Peru. Glob. Chang. Biol. 18, 164-178 (2012).

15. Draper, F. C. et al. The distribution and amount of carbon in the largest peatland complex in Amazonia. Environ. Res. Lett. 9, 1-12 (2014).

16. Lähteenoja, O. \& Page, S. High diversity of tropical peatland ecosystem types in the Pastaza-Marañón basin, Peruvian Amazonia. J. Geophys. Res. Biogeosciences 116, (2011).

17. Sjögersten, S. et al. Tropical wetlands: A missing link in the global carbon cycle? Global Biogeochem. Cycles 28, 1371-1386 (2014).

18. Bergamaschi, P. et al. Satellite charactography of atmospheric methane from SCIAMACHY on board ENVISAT: 2. Evaluation based on inverse model simulations. $J$. Geophys. Res. Atmos. 112, (2007).

19. Couwenberg, J., Dommain, R. \& Joosten, H. Greenhouse gas fluxes from tropical peatlands in south-east Asia. Glob. Chang. Biol. 16, 1715-1732 (2010).

20. Salati, E., Dall'Olio, A., Matsui, E. \& Gat, J. R. Recycling of water in the Amazon Basin: An isotopic study. Water Resour. Res. 15, 1250-1258 (1979).

21. Devol, A. H., Richey, J. E., Forsberg, B. R. \& Martinelli, L. A. Seasonal dynamics in methane emissions from the Amazon River floodplain to the troposphere. 95, (1990).

22. Potter, C., Melack, J. M. \& Engle, D. Modeling methane emissions from amazon floodplain ecosystems. Wetlands 34, 501-511 (2014).

23. Murphy, W., Carlos Berrio, J., Boom, A., Page, S. \& Arn Teh, Y. Temporal variability in methane fluxes from tropical peatlands within the Peruvian Amazon. in Geophysical Research Abstracts 18, EGU2016-16391 (2016).

24. Van Haren, J. L. M. \& Cadillo-Quiroz, H. Methane flux of Amazonian peatland ecosystems: large ecosystem fluxes with substantial contribution from palm (Mauritia Flexuosa) stem emissions. in American Geophysical Union, Fall Meeting 2015, abstract \#B43J-06 (2015).

25. van Lent, J., Hergoualc'h, K., Verchot, L., van Groeningen, J. W. \& Oenema, O. The effect of peat swamp forest degradation on greenhouse gas fluxes in the Peruvian Amazon. 19th EGU Gen. Assem. EGU2017, Proc. from Conf. held 23-28 April. 2017 Vienna, Austria., p.18822 19, 18822 (2017). 
26. Teh, Y. A., Murphy, W. A., Berrio, J., Boom, A. \& Page, S. E. Seasonal variability in methane and nitrous oxide fluxes from tropical peatlands in the western Amazon basin. Biogeosciences 14, 3669-3683 (2017).

27. Miller, J. B. et al. Airborne measurements indicate large methane emissions from the eastern Amazon basin. Geophys. Res. Lett. 34, (2007).

28. Wright, E. L., Black, C. R., Turner, B. L. \& Sjögersten, S. Environmental controls of temporal and spatial variability in $\mathrm{CO} 2$ and $\mathrm{CH} 4$ fluxes in a neotropical peatland. Glob. Chang. Biol. 19, 3775-3789 (2013).

29. Inubushi, K. et al. Factors influencing methane emission from peat soils: Comparison of tropical and temperate wetlands. Nutr. Cycl. Agroecosystems 71, 93-99 (2005).

30. Sjögersten, S., Cheesman, A. W., Lopez, O. \& Turner, B. L. Biogeochemical processes along a nutrient gradient in a tropical ombrotrophic peatland. Biogeochemistry 104, 147-163 (2011).

31. Wright, E. L., Black, C. R., Turner, B. L. \& Sjögersten, S. Environmental controls of temporal and spatial variability in $\mathrm{CO} 2$ and $\mathrm{CH} 4$ fluxes in a neotropical peatland. Glob. Chang. Biol. 19, 3775-3789 (2013).

32. Inubushi, K., Furukawa, Y., Hadi, A., Purnomo, E. \& Tsuruta, H. Seasonal changes of $\mathrm{CO} 2, \mathrm{CH} 4$ and $\mathrm{N} 2 \mathrm{O}$ fluxes in relation to land-use change in tropical peatlands located in coastal area of South Kalimantan. Chemosphere 52, 603-608 (2003).

33. Bellisario, L. M., Bubier, J. L., Moore, T. R. \& Chanton, J. P. Controls on CH4 emissions from a northern peatland. Global Biogeochem. Cycles 13, 81 (1999).

34. Jaenicke, J., Wösten, H., Budiman, A. \& Siegert, F. Planning hydrological restoration of peatlands in Indonesia to mitigate carbon dioxide emissions. Mitig. Adapt. Strateg. Glob. Chang. 15, 223-239 (2010).

35. Ye, R. et al. PH controls over anaerobic carbon mineralization, the efficiency of methane production, and methanogenic pathways in peatlands across an ombrotrophicminerotrophic gradient. Soil Biol. Biochem. 54, 36-47 (2012).

36. Wright, E. L. et al. Contribution of subsurface peat to $\mathrm{CO} 2$ and $\mathrm{CH} 4$ fluxes in a neotropical peatland. Glob. Chang. Biol. 17, 2867-2881 (2011).

37. Bridgham, S. D., Updegraff, K. \& Pastor, J. Carbon, nitrogen, and phosphorus mineralization in northern wetlands. Ecology 79, 1545-1561 (1998).

38. Keller, J. K. \& Bridgham, S. D. Pathways of anaerobic carbon cycling across an ombrotrophic-minerotrophic peatland gradient. Limnol. Oceanogr. 52, 96-107 (2007). 
39. Cresto Aleina, F. et al. Modeling micro-topographic controls on boreal peatland hydrology and methane fluxes. Biogeosciences 12, 5689-5704 (2015).

40. Bubier, J., Costello, a., Moore, T. R., Roulet, N. T. \& Savage, K. Microtopography and methane flux in boreal peatlands, northern Ontario, Canada. Canadian Journal of Botany 71, 1056-1063 (1993).

41. Lai, D. Y. F. Methane Dynamics in Northern Peatlands: A Review. Pedosphere 19, 409-421 (2009).

42. Sundari, S., Hirano, T., Yamada, H., Kusin, K. \& Limin, S. Effect of groundwater level on soil respiration in tropical peat swamp forests. J. Agric. Meteorol. 68, 121-134 (2012).

43. Chimner, R. A. Soil respiration rates of tropical peatlands in Micronesia and Hawaii. Wetlands 24, 51-56 (2004).

44. Hirano, T., Jauhiainen, J., Inoue, T. \& Takahashi, H. Controls on the carbon balance of tropical peatlands. Ecosystems 12, 873-887 (2009).

45. Rydin, H. \& Jeglum, J. K. The Biology of Peatlands. (Oxford University Press, 2013). doi:10.1093/acprof:osob1/9780199602995.001.0001

46. Chimner, R. a. \& Ewel, K. C. Differences in carbon fluxes between forested and cultivated micronesian tropical peatlands. Wetl. Ecol. Manag. 12, 419-427 (2004).

47. Walker, T. S., Bais, H. P., Grotewold, E. \& Vivanco, J. M. Root exudation and rhizosphere biology. Plant Physiol. 132, 44-51 (2003).

48. Aulakh, M. S., Wassmann, R., Bueno, C. \& Rennenberg, H. Impact of root exudates of different cultivars and plant development stages of rice (Oryza sativa L.) on methane production in a paddy soil. Plant Soil 230, 77-86 (2001).

49. Bridgham, S. D., Cadillo-Quiroz, H., Keller, J. K. \& Zhuang, Q. Methane emissions from wetlands: Biogeochemical, microbial, and modeling perspectives from local to global scales. Glob. Chang. Biol. 19, 1325-1346 (2013).

50. Crow, S. E. \& Wieder, R. K. Sources of CO2 emission from a northern peatland: root respiration, exudation, and decomposition. Ecology 86, 1825-1834 (2005).

51. Smith, K. E. \& Luna, T. O. Radial oxygen loss in wetland plants: potential impacts on remediation of contaminated sediments. J. Environ. Eng. 139, 496-501 (2013). 
52. Bhullar, G. S., Edwards, P. J. \& Olde Venterink, H. Variation in the plantmediated methane transport and its importance for methane emission from intact wetland peat mesocosms. J. Plant Ecol. 6, 298-304 (2013).

53. Koelbener, A., Ström, L., Edwards, P. J. \& Olde Venterink, H. Plant species from mesotrophic wetlands cause relatively high methane emissions from peat soil. Plant Soil 326, $147-158$ (2010).

54. Purvaja, R., Ramesh, R. \& Frenzel, P. Plant-mediated methane emission from an Indian mangrove. Glob. Chang. Biol. 10, 1825-1834 (2004).

55. Pangala, S. R., Moore, S., Hornibrook, E. R. C. \& Gauci, V. Trees are major conduits for methane egress from tropical forested wetlands. New Phytol. 197, 524-531 (2013).

56. Pangala, S. R., Hornibrook, E. R. C., Gowing, D. J. \& Gauci, V. The contribution of trees to ecosystem methane emissions in a temperate forested wetland. Global Change Biology 21, (2015).

57. Rice, A. L. et al. Emissions of anaerobically produced methane by trees. Geophys. Res. Lett. 37, 1-6 (2010).

58. De Granville, J. J. Aperçu Sur La Struture Des Pneumatophores De Deux Espèces Des Sols Hydromorphes En Guyane. ORSTOM. série Biol. 3-22 (1974).

59. Chasar, L. \& Chanton, J. Radiocarbon and stable carbon isotopic evidence for transport and transformation of dissolved organic carbon, dissolved inorganic carbon, and CH4 in a. Global Biogeochem. Cycles 14, 1095-1108 (2000).

60. Chanton, J. P. et al. Radiocarbon evidence for the importance of surface vegetation on fermentation and methanogenesis in contrasting types of boreal peatlands. Global Biogeochem. Cycles 22, 1-11 (2008).

61. Hoyt, A. et al. Methanogenesis in Peat Bogs - Insights from 14C Data Synthesis and Modeling. in American Geophysical Union, Fall Meeting 2015, abstract \#B43J-04 (2015).

62. Hribljan, J. A., Kane, E. S., Pypker, T. G. \& Chimner, R. C. The effect of longterm water table manipulations on dissolved organic carbon dynamics in a poor fen peatland. J. Geophys. Res. Biogeosciences 119, 1-19 (2014).

63. Leifeld, J., Steffens, M. \& Galego-Sala, A. Sensitivity of peatland carbon loss to organic matter quality. Geophys. Res. Lett. 39, 1-6 (2012). 
64. Gandois, L. et al. Impact of deforestation on solid and dissolved organic matter characteristics of tropical peat forests: Implications for carbon release. Biogeochemistry 114, 183-199 (2013).

65. Gandois, L. et al. Origin, composition, and transformation of dissolved organic matter in tropical peatlands. Geochim. Cosmochim. Acta 137, 35-47 (2014).

66. Cook, S. et al. Quantifying tropical peatland dissolved organic carbon (DOC) using UV-visible spectroscopy. Water Res. 115, 229-235 (2017).

67. Hribljan, J., Kane, E. \& Chimner, R. Implications of Altered Hydrology for Substrate Quality and Trace Gas Production in a Poor Fen Peatland Wetland Soils. Soil Sci. Soc. Am. J. (2017). doi:10.2136/sssaj2016.10.0322

68. Hutchinson, G. \& Mosier, A. Improved soil cover method for field measurement of nitrous oxide fluxes. Soil Sci. Soc. Am. J. 45, 311-316 (1981).

69. Davidson, E. A., Savage, K., Verchot, L. V. \& Navarro, R. Minimizing artifacts and biases in chamber-based measurements of soil respiration. Agric. For. Meteorol. 113, 21-37 (2002).

70. LI-COR. Using the LI-8100 System to Collect Air Samples for Estimating Soil Trace Gas Flux.

71. Hansen, A. M. et al. Optical properties of dissolved organic matter (DOM): Effects of biological and photolytic degradation. Limnol. Oceanogr. 61, 1015-1032 (2016).

72. Kang, S. \& Xing, B. Humic acid fractionation upon sequential adsorption onto goethite. Langmuir 24, 2525-2531 (2008).

73. Kiss, K., Szalai, Z., Jakab, G., Madarász, B. \& Zboray, N. in Soil Carbon 127136 (Springer International Publishing, 2014). doi:10.1007/978-3-319-04084-4_13

74. Inglett, K. S. et al. in Methods in Biogeochemistry of Wetlands 407-425 (Soil Science Society of America, 2013). doi:10.2136/sssabookser10.c21

75. Lähteenoja, O., Ruokolainen, K., Schulman, L. \& Alvarez, J. Amazonian floodplains harbour minerotrophic and ombrotrophic peatlands. Catena 79, 140-145 (2009).

76. Hammer, Ø., Harper, D. A. T. a. T. \& Ryan, P. D. PAST: Paleontological Statistics Software Package for Education and Data Analysis. Palaeontol. Electron. 4(1), $1-9(2001)$. 
77. Chimner, R. A., Lemly, J. M. \& Cooper, D. J. Mountain Fen Distribution, Types and Restoration Priorities, San Juan Mountains, Colorado, USA. Wetlands 30, 1-9 (2010).

78. Littell, R. C., Milliken, G. A., Stroup, W. W., Wolfinger, R. D. \& Schabenberger, O. SAS for mixed models. Inc., Cary, NC (SAS Institute Inc., 2006).

79. Abdalla, M. et al. Emissions of methane from northern peatlands: a review of management impacts and implications for future management options. Ecol. Evol. 6, 7080-7102 (2016).

80. Belger, L., Forsberg, B. R. \& Melack, J. M. Carbon dioxide and methane emissions from interfluvial wetlands in the upper Negro River basin, Brazil.

Biogeochemistry 105, 171-183 (2011).

81. Winton, R. S., Flanagan, N. \& Richardson, C. J. Neotropical peatland methane emissions along a vegetation and biogeochemical gradient. PLoS One 12, 1-12 (2017).

82. Webb, A. J. et al. CH4 concentrations over the Amazon from GOSAT consistent with in situ vertical profile data. J. Geophys. Res. Atmos. 121, 11,006-11,020 (2016).

83. Zaccone, C. \& Miano, T. M. Influence of water table changes on peat features and humification processes. in Geophysical Research Abstracts 12, (2010).

84. Mulkey, S. S., Chazdon, R. L. \& Smith, A. P. Tropical Forest Plant Ecophysiology. (Springer US, 1996).

85. DiTomaso, J. M. \& Kyser, G. B. Weed Control in Natural Areas in the Western United States. (Weed Research Center, University of California, 2013).

86. Jung, J., Lee, S. C. \& Choi, H. K. Anatomical patterns of aerenchyma in aquatic and wetland plants. J. Plant Biol. 51, 428-439 (2008).

87. Barton, D. A., Overall, R. L. \& Thomson, J. A. Structure and development of the lateral-line aerenchyma in bracken ferns (Pteridium: Dennstaedtiaceae). Int. J. Plant Sci. 176, 662-669 (2015).

88. Pangala, S. R., Gauci, V., Hornibrook, E. R. C. \& Gowing, D. J. Tree-mediated methane emissions from tropical and temperate peatlands . 14, 2012 (2012).

89. Agus, F., Hairiah, K. \& Mulyani, A. Measuring carbon stock in peat soil: practical guidelines. World agroforestry Centre-ICRAF Southeast Asia and Indonesian Centre for Agricultural Land Resources Research and Development, Bogor (World Agroforestry Centre (ICRAF) Southeast Asia Regional Program, 2011). 
90. Rocha Campos, J. R. da, Silva, A. C., Fernandes, J. S. C., Ferreira, M. M. \& Silva, D. V. Water retention in a peatland with organic matter in different decomposition stages. Rev. Bras. Ciência do Solo 35, 1217-1227 (2011).

91. Manzi, M. \& Coomes, O. T. Managing Amazonian palms for community use: A case of aguaje palm (Mauritia flexuosa) in Peru. For. Ecol. Manage. 257, 510-517 (2009).

92. Megonigal, J. P., Hines, M. E. \& Visscher, P. T. in Treatise on Geochemistry 317-424 (Elsevier, 2003). doi:10.1016/B0-08-043751-6/08132-9

93. Moore, S. et al. Deep instability of deforested tropical peatlands revealed by fluvial organic carbon fluxes. Nature 493, 660-663 (2013). 